• 研究报告・

\title{
中国佛教寺庙植物多样性和佛教树种替代
}

\author{
王新阳 靳 程 黄 力 周礼华 郑明铭 钱深华 杨永川*
}

(重庆大学三峡库区生态环境教育部重点实验室, 重庆 400045)

\begin{abstract}
摘要：佛教是我国的主要宗教之一, 佛教寺庙作为佛教文化的物质载体, 对区域生物多样性的保护具有重要意 义。本研究收集了中国191座寺庙的树种名录, 分析了不同地区寺庙的树种组成、分布格局及影响因素, 以明确寺 庙在生物多样性保护中的作用。结果表明: (1)全国191座寺庙共收集到树种1,059种, 隶属116科410属, 大多数树种 (773种)仅出现在1-2座寺庙中; (2)寺庙树种中含有大量乡土植物, 并且保存了丰富的受威胁树种(94种), 具有较高 的生物多样性保护价值; (3)不同气候带的佛教树种组成差异较大, 主要受气候因子限制; (4)佛教树种具有清晰的 树种替代现象, 由南向北原始佛教树种逐渐由形态相似的本土物种(替代佛教树种)替代。以上结果表明中国寺庙 中保存了非常丰富的植物资源, 有效地保护和利用寺庙植物资源对维持区域生物多样性和提升城市绿化水平具有 积极作用。
\end{abstract}

关键词: 寺庙园林; 佛教树种; 佛教树种替代; 生物多样性保护

\section{Plant diversity and species replacement in Chinese Buddhist temples}

\begin{abstract}
Xinyang Wang, Cheng Jin, Li Huang, Lihua Zhou, Mingming Zheng, Shenhua Qian, Yongchuan Yang*
Key Laboratory of the Three Gorges Reservoir Region's Eco-Environment, Ministry of Education, Chongqing University, Chongqing 400045
\end{abstract}

\begin{abstract}
Buddhism is one of the main religions in China. As the material carrier of Buddhist culture, Buddhist temples play an important role in preserving regional biodiversity. In this study, we cataloged the tree species in 191 temples across China. Then, we analyzed the species composition, geographical distribution pattern, and the impact factors of Buddhist tree species distribution in different regions to clarify the role of temples in biodiversity conservation. The results showed that: (1) From across 191 temples, we observed a total of 1,059 tree species, belonging to 116 families and 410 genera with most species $(n=773)$ occurred in only one or two temples. (2) Temple gardens were rich in native and threatened tree species $(n=$ 94), and thus, are of high biodiversity conservation value. (3) The tree species composition of Buddhist temples in different climatic zones was quite different. (4) Tree species across temples had a distinct replacement phenomenon where original Buddhist tree species were gradually replaced by native species similar to the native flora, from south to north. The above results suggest that Chinese temples have very rich plant resource and that their effective protection may play a positive role in maintaining regional biodiversity and improving urban greening.
\end{abstract}

Key words: temple gardens; Buddhist tree species; Buddhist tree species replacement; biodiversity conservation

文化与生物多样性保护之间的相互联系是目 前生物多样性研究领域的热点问题之一(Berkes, 2009; Jimoh et al, 2012; Lohbeck et al, 2016; 杨立新 等, 2019)。宗教文化是这些文化类型中的典型代表,
被证明在区域生物多样性保护中发挥着重要的积 极作用。比如大量研究表明, 欧洲和非洲部分地区 的教堂林的生物多样性显著高于周围地区, 甚至高 于当地的自然保护区(Dudley et al, 2010; Aerts et al,

收稿日期: 2019-12-07; 接受日期: 2020-02-14

基金项目: 重庆市技术创新与应用示范专项重点研发项目(cstc2018jszX-zdyfxmX0007)和重庆市研究生科研创新项目(CYS18028)

* 通讯作者 Author for correspondence. E-mail: ycyang@cqu.edu.cn 
2016; Frascaroli et al, 2016; Kowarik et al, 2016)。在 东亚和南亚, 佛教是最盛行的宗教之一(Tucker \& Williams，2008)。佛教自然圣境(比如神山、圣湖) 保护生物多样性的案例在印度、韩国以及中国云南 省和喜马拉雅地区大量存在(Salick et al, 2007; Anthwal et al, 2010)。然而, 佛教寺庙作为佛教自然 圣境的主要组成部分, 目前对其生物多样性保护作 用的认识不足。

佛教寺庙由寺庙建筑物和寺庙园林构成, 是佛 教文化的物质载体。寺庙园林包含寺庙庭院栽培植 物、“寺产林” 以及寺庙周围的森林等(艾菊红, 2013)。寺庙园林以斑块形式存在于各类受人类干扰 的景观中, 成为区域生物多样性的热点(Aerts et al, 2016)。寺庙园林对生物多样性的保护主要体现在以 下两个方面: (1)对特定植物的传播、引种与保护(Liu et al, 2002)。佛教植物伴随佛教文化的传播而迁移, 但受环境和气候条件的限制, 大多来源于佛教发源 地的热带植物并不适合在中国中北部及高原等寒 冷地区生存, 因而许多中国本土的植物被作为佛教 植物的替代种而在佛教寺庙中大量栽培(金荷仙和 华海镜，2004; 王早娟，2017)。比如菩提树(Ficus religiosa) 在中国的主要替代植物为银杏 (Ginkgo biloba), 目前中国许多银杏古树都被保存在佛教寺 庙或者佛教名山中。佛教寺庙对这些植物的物种多 样性和遗传多样性的保护具有重要作用(Zhao et al, 2019)。(2)保护了城市和乡村等干扰严重的人为景 观中的残存自然植被斑块(艾菊红, 2013; Aerts et al, 2016; Kowarik et al, 2016)。这些残存自然植被斑块 不仅为诸多动物提供了生境, 还是当地宝贵的乡土 物种基因库和资源库, 在生态修复过程中能够起到 至关重要的作用(杨永川等, 2007)。

目前关于寺庙植物的研究主要集中于佛教植 物文化探索(颜晓佳等, 2013; 高川等, 2015)、物种 资源调查(胡新月等, 2014)、群落结构分析(叶海跃 等, 2009)和园林景观配置(陈永贵等, 2016)等方面。 在研究尺度上, 侧重单个或局部地区寺庙(宗桦和 张楠, 2013), 极少数涉及多个地区寺庙植物的比较 (李林等, 2011), 缺乏寺庙物种分布格局及其影响因 素的大尺度研究。中国有34,000余座佛教寺庙以斑 块形式存在于各类景观中(国家宗教事务局宗教基 础信息查询系统; http://www.sara.gov.cn/zjhdcsjbxx/ index.jhtml/), 这些寺庙中到底保存了多少植物物
种? 保护了哪些植物? 其在生物多样性保护中究竟 发挥着什么样的作用? 目前并不清楚。本研究收集 了中国191座寺庙的树木名录，分析了不同地区佛 教寺庙树木的物种组成、分布格局及影响因素, 探 讨了佛教寺庙对生物多样性保护的作用，以加深对 佛教寺庙生物多样性保护功能的认识, 为区域生物 多样性保护提供新的视角。

\section{材料与方法}

\section{1 数据收集}

\subsection{1 寺庙树木名录获取}

以“寺庙园林” “寺庙植物”和“寺庙绿化”等为关 键词在中国知网(CNKI; http://www.cnki.net/)和万方 数据库 (http://www.wanfangdata.com.cn/) 中进行检 索，获取相关文献(附录1)。提取文献中寺庙树木名 录, 并记录寺庙名称、建成时间、地理位置等信息 (附录2)。为获取更完整的寺庙树种名录数据, 在中 国植物图像库(PPBC; http://ppbc.iplant.cn/)、国家标 本资源共享平台(NSII; http://www.nsii.org.cn/)、各省 市林业网站等平台对这些寺庙的树种信息进行补 充收集。其中, 在文献中收集到寺庙树种名录数据 1,480 条, 在PPBC等平台中收集到寺庙树种名录数 据2,023条。本研究只关注寺庙内的树种, 不包含寺 庙周边森林。根据文献或所使用各类平台中对树种 地点的描述判断树种是否在寺庙内。此外, 本研究 不考虑佛教派别的差异，对所有收集到的寺庙树种 名录数据进行统一分析。

\subsection{2 树种信息确定}

树种中文名、拉丁名、科、属、生活型、地理来 源等信息以Flora of China (FOC; http://foc.iplant.cn/) 为准。根据地理来源信息, 在本省有自然分布的植 物视为该省寺庙的乡土植物。参照《中国高等植物 受威胁物种名录》(覃海宁等, 2017)确定各树种受威 胁等级。同时，通过查询文献、书籍资料(详见附录 3), 收集各树种的文化含义，具有佛教文化含义(如 觉悟、无忧、涅槃、小因大果、清心寡欲等佛教寓 意; 刻经、佛珠、花供、果供、香供等佛教用途) 的树种被称为佛教树种，其中“五树六花” (除草本 植物)和来源于佛教发源地的佛教树种称为原始佛 教树种，其他佛教树种称为替代佛教树种。

\subsection{3 寺庙环境数据收集}

寺庙经纬度与海拔在谷歌地球软件(7.1.7版本) 
中查询获得; 寺庙年均温与年降水量在中国气象局 气象数据中心(http://data.cma.cn/)查询获取, 选择就 近气象站数据 $($ 气象站距寺庙1.0-131.9 km不等, 平 均距离29.5 km), 取30年(1981-2010年)的平均值。 参照《中国气候》(丁一汇, 2013), 可将191座寺庙所 在地划分到 6 个气候带中, 分别为热带与南亚热带 (tropical and southern subtropical zone, SS)、中亚热 带(middle subtropical zone, MS)、北亚热带(northern subtropical zone, NS)、暖温带(warm temperate zone, $\mathrm{WT}$ )、中温带(middle temperate zone, MT)和高原温 带(plateau temperate zone, PT) (图1), 分布在以上气 候带的寺庙分别有19、43、56、56、10和7座。

\section{2 数据分析}

将佛教树种地理来源信息叠加绘制中国佛教 树种地理来源热力图, 分析原始佛教树种和替代佛 教树种来源的热点区域。采用单因素方差和多重比 较分析方法, 比较不同气候带寺庙乡土树种比例和 佛教树种比例; 采用秩和检验和多重比较分析方法,

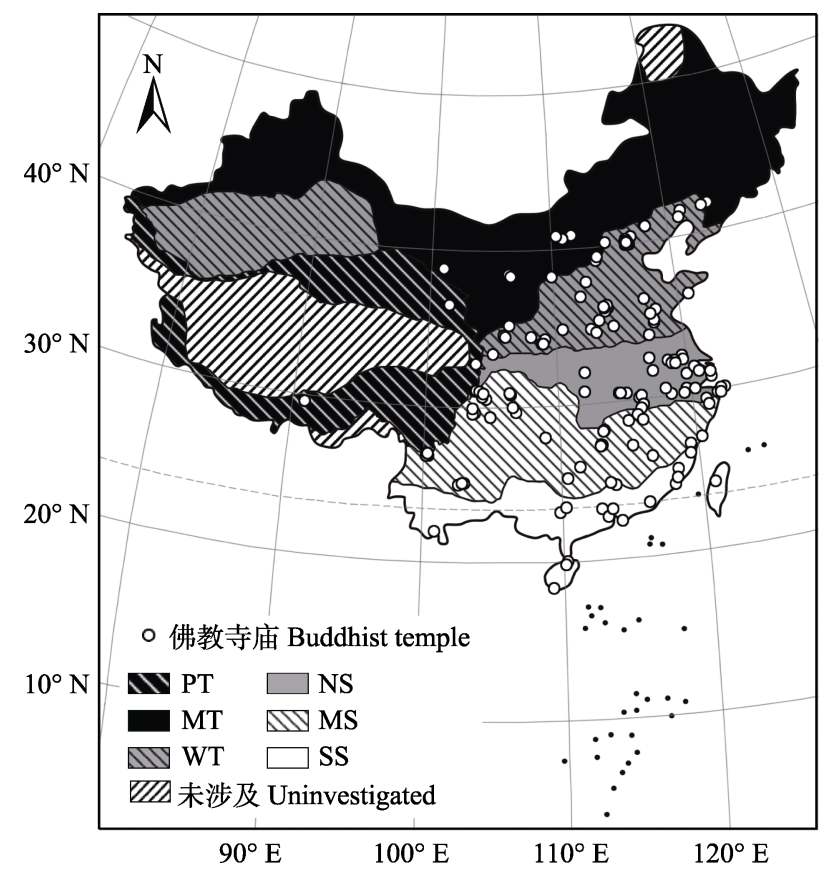

图1 本研究分析的191座佛教寺庙的地理分布。SS: 热带与 南亚热带; MS: 中亚热带; NS: 北亚热带; WT: 暖温带; MT: 中温带; PT: 高原温带。

Fig. 1 Map of China showing the 191 Buddhist temples in this study. SS, Tropical and southern subtropical zone; MS, Middle subtropical zone; NS, Northern subtropical zone; WT, Warm temperate zone; MT, Middle temperate zone; PT, Plateau temperate zone.
佛教文化含义的佛教树种在中国的分布情况，绘制 典型佛教树种分布图，揭示佛教树种的替代关系。 选择经度、纬度、海拔3个地理因子，年均温、年降 水量两个气候因子，以及寺庙建成时间这一人文因 子，对寺庙佛教树种组成进行基于辛普森距离 (Simpson dissimilarity index, $\beta_{\text {SIM }}$ ) 的圥余分析 (distance-based redundancy analysis, db-RDA), 探讨 影响佛教树种分布的主要因素(Yan \& Yang, 2017)。 $\beta_{\text {SIM }}$ 计算公式如下:

$$
\beta_{\mathrm{SIM}}=\operatorname{Min}(b, c) /(\operatorname{Min}(b, c)+a)
$$

式中, $a$ 是两座寺庙共有的物种数, $b$ 和 $c$ 分别是每座 寺庙特有的物种数。 $\beta_{\mathrm{SIM}}$ 的值介于 $0-1$ 之间, 值越高 表示两座寺庙之间物种组成的差异越大。

所有分析和绘图在R3.4.2中完成。

\section{2 结果}

\section{1 寺庙物种组成}

本研究在全国191座寺庙中共记录树木1,059种, 隶属116科410属，其中佛教树木 113 种，隶属38科63 属。树种最多的科为蓄薇科, 含 110 种; 最多的属为 枫属(Acer), 含25种(表1)。出现频率较高的树种为 银杏、木犀(Osmanthus fragrans)、圆柏(Juniperus chinensis)、侧柏(Platycladus orientalis)和槐(Sophora japonica); 出现频率前 20 位的树种中有 10 种为佛教 树种(表2)。大部分树种(773种)仅出现在1-2座寺庙 中，占物种总数的 $73 \%$ (图2a)。其中包含58种佛教

表1 191座寺庙树种数最多的前10个科与属

Table 1 Number of tree species in the top 10 families and genera in 191 Buddhist temples

\begin{tabular}{|c|c|c|c|}
\hline $\begin{array}{l}\text { 科 } \\
\text { Family }\end{array}$ & $\begin{array}{l}\text { 种数 } \\
\text { No. } \\
\text { of species }\end{array}$ & $\begin{array}{l}\text { 属 } \\
\text { Genus }\end{array}$ & $\begin{array}{l}\text { 种数 } \\
\text { No. } \\
\text { of species }\end{array}$ \\
\hline 蓄薇科 Rosaceae & 110 & 枫属 Acer & 25 \\
\hline 壳斗科 Fagaceae & 45 & 卫矛属 Euonymus & 19 \\
\hline 樟科 Lauraceae & 45 & 榕属 Ficus & 19 \\
\hline 豆科 Fabaceae & 44 & 杜鹃花属 Rhododendron & 18 \\
\hline 木兰科 Magnoliaceae & 34 & 山茶属 Camellia & 17 \\
\hline 山茶科 Theaceae & 34 & 樱属 Cerasus & 14 \\
\hline 大戟科 Euphorbiaceae & 33 & 松属 Pinus & 14 \\
\hline 桑科 Moraceae & 28 & 蔷薇属 Rosa & 13 \\
\hline 木犀科 Oleaceae & 28 & 悬钩子属 Rubus & 13 \\
\hline 槭树科Aceraceae & 25 & 柳属 Salix & 13 \\
\hline
\end{tabular}


表2 191座寺庙中出现频率前20的树种及其佛教文化含义

Table 2 The top 20 commonly used tree species and their Buddhist cultural values in 191 Buddhist temples

\begin{tabular}{|c|c|c|c|}
\hline 物种 Species & 科 Family & 频率 Frequency (\%) & 佛教文化含义 Buddhist cultural values \\
\hline 银杏 Ginkgo biloba & 银杏科 Ginkgoaceae & 48.2 & $\begin{array}{l}\text { 菩提树替代树 } \\
\text { Alternative tree species of Ficus religiosa }\end{array}$ \\
\hline 木犀 Osmanthus fragrans & 木犀科 Oleaceae & 32.5 & - \\
\hline 圆柏 Juniperus chinensis & 柏科 Cupressaceae & 31.4 & 佛教香料植物 Buddhist aromatic plant \\
\hline 侧柏 Platycladus orientalis & 柏科 Cupressaceae & 29.8 & 佛教香料植物 Buddhist aromatic plant \\
\hline 槐 Sophora japonica & 豆科 Fabaceae & 29.3 & - \\
\hline 樟 Cinnamomum camphora & 樟科 Lauraceae & 22.5 & 佛教香料植物 Buddhist aromatic plant \\
\hline 紫薇 Lagerstroemia indica & 千屈菜科 Lythraceae & 19.4 & - \\
\hline 玉兰 Yulania denudata & 木兰科 Magnoliaceae & 18.3 & $\begin{array}{l}\text { 山玉兰替代树 } \\
\text { Alternative tree species of Lirianthe delavayi }\end{array}$ \\
\hline 蜡梅 Chimonanthus praecox & 蜡梅科 Calycanthaceae & 17.8 & - \\
\hline 柏木 Cupressus funebris & 柏科 Cupressaceae & 16.2 & 佛教香料植物 Buddhist aromatic plant \\
\hline 雪松 Cedrus deodara & 松科 Pinaceae & 16.2 & - \\
\hline 罗汉松 Podocarpus macrophyllus & 罗汉松科 Podocarpaceae & 14.7 & $\begin{array}{l}\text { 种子象征修行僧 } \\
\text { The seed symbolizes the image of monk }\end{array}$ \\
\hline 鸡爪枫 Acer palmatum & 槭树科 Aceraceae & 13.6 & - \\
\hline 油松 Pinus tabuliformis & 松科 Pinaceae & 13.6 & - \\
\hline 山茶 Camellia japonica & 山茶科 Theaceae & 13.1 & $\begin{array}{l}\text { 象征禅宗清心寡欲 Symbolizing a pure heart } \\
\text { and few desires in Dhyana's thought }\end{array}$ \\
\hline 臭椿 Ailanthus altissima & 苦木科 Simaroubaceae & 12.6 & - \\
\hline 南天竹 Nandina domestica & 小檗科 Berberidaceae & 12.6 & $\begin{array}{l}\text { 寓意消灾除忧 Symbolizing the elimination } \\
\text { of disaster and worry }\end{array}$ \\
\hline 杜鹃 Rhododendron simsii & 杜鹃花科 Ericaceae & 12.0 & - \\
\hline 朴树 Celtis sinensis & 榆科 Ulmaceae & 12.0 & - \\
\hline 石榴 Punica granatum & 千屈菜科 Lythraceae & 11.5 & $\begin{array}{l}\text { 寓意小因大果 } \\
\text { Symbolizing small cause making big fruit }\end{array}$ \\
\hline
\end{tabular}
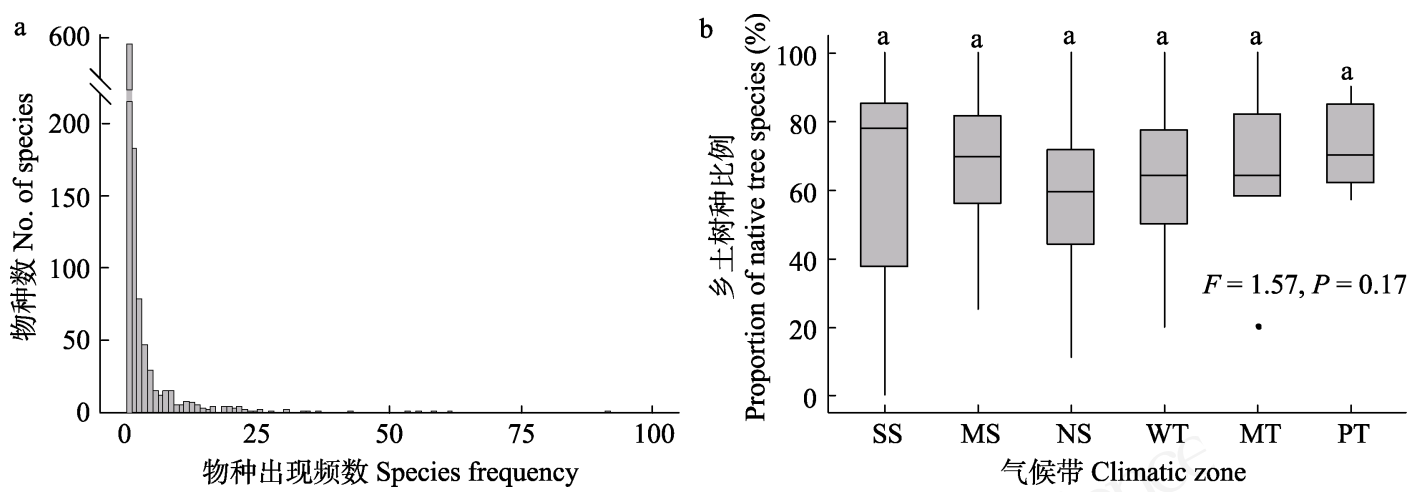

图2 191座寺庙中物种出现频数(a)和不同气候带寺庙乡土树种比例(b)。采用单因素方差和多重比较分析，相同小写字母表 示差异不显著。气候带代号同图1。

Fig. 2 The species frequency of all species in 191 Buddhist temples (a) and the proportion of native tree species in different climatic zones (b). One-way ANOVA and multiple comparison analysis were used to compare the proportion of native tree species among the Buddhist temples in different climatic zones. The same letters above the boxes indicate insignificant difference $(P=0.17)$ based on multiple comparisons. The abbreviations of climatic zones are the same as Fig. 1.

树种，其余为非佛教树种，以蓄薇科(79种)、豆科 (37种)、樟科(32种)、壳斗科(29种)和山茶科(28种) 为最多。此外, 寺庙中树种多为乡土树种, 各气候
带寺庙中乡土树种比例无显著差异，191座寺庙乡 土植物比例平均值为 $63.8 \%$ (图2b)。

1,059 种树种中有94种被列入《中国高等植物受 
威胁物种名录》(覃海宁等, 2017), 易危、濒危和极 危树种分别有 $55 、 27$ 和12种。其中，易危种包含金 钱松 (Pseudolarix amabilis)、罗汉松 (Podocarpus macrophyllus)、楠木(Phoebe zhennan)等; 濒危种包 含红豆树 (Ormosia hosiei)、毗黎勒 (Terminalia bellirica)、云南乷罗双(Shorea assamica) 等; 极危种 包含银杏、水杉(Metasequoia glyptostroboides)、普 陀我烏枥(Carpinus putoensis)、天目铁木(Ostrya rehderiana)等。大部分寺庙(143座)中保存有受威胁 树种。

\section{2 佛教树种来源}

原始佛教树种有 15 种, 主要来源地为印度 (12 种) (图3a)。替代佛教树种有98种, 主要来源于中国 南部, 其中云南(48种)、广东(47种)、广西(45种)、 贵州(43种)和四川(43种)是替代佛教树种来源的热 点区域(图3b)。热带与南亚热带寺庙中原始佛教树 种比例显著高于其他气候带寺庙 $(P<0.01)$, 中温带 和高原温带寺庙中没有原始佛教树种存在(图4a)。 各气候带寺庙中佛教树种比例无显著差异(图4b)。

\section{3 佛教树种物种组成影响因素和树种替代}

基于 $\beta_{\mathrm{SIM}}$ 的 $\mathrm{db}-\mathrm{RDA}$ 分析结果(图5)显示第一轴 的解释率为 $50.2 \%$, 第二轴的解释率为 $26.8 \%$, 二者 解释率之和高达 $77.0 \%$ 。第一轴主要解释变量为年 降水量、纬度与年均温, 解释变量双序图得分分别 为 $89.8 \% 、-87.8 \%$ 和 $73.5 \%$; 第二轴主要解释变量为 海拔、经度和寺庙建成时间，解释变量双序图得分 分别为 $-39.8 \%$ 、20.4\%和15.8\%。中国不同地区寺庙 佛教树种组成不同，基本能够按照气候带进行区分 (图5)。db-RDA分析表明，相较于寺庙建成时间这一 人文因子，全国寺庙佛教树种分布受年均温、年降
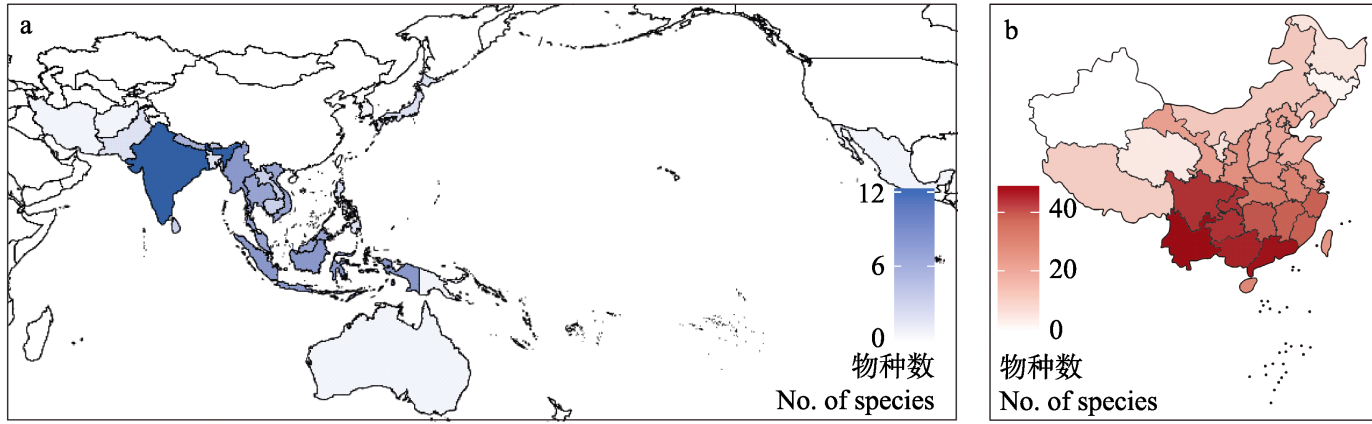

图3 中国191座寺庙中佛教树种的地理来源。(a)原始佛教树种; (b)替代佛教树种。

Fig. 3 Geographical origins of Buddhist tree species in 191 Buddhist temples. (a) Original Buddhist tree species; (b) Alternative Buddhist tree species.
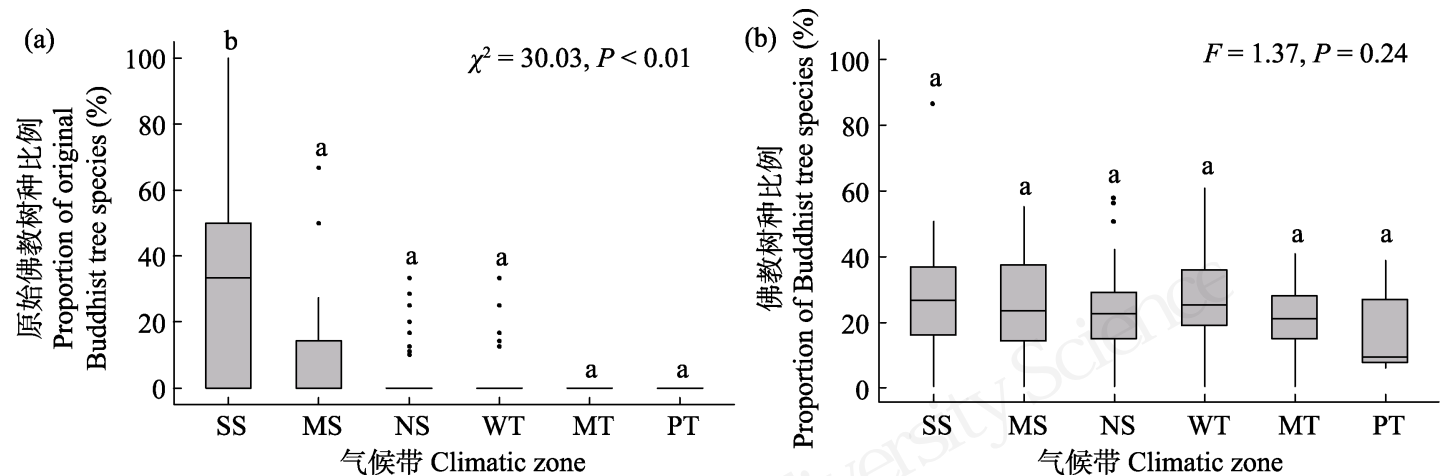

图4 不同气候带寺庙中原始佛教树种比例(a)和佛教树种比例(b)。(a)采用秩和检验和多重比较分析; (b)采用单因素方差和多 重比较分析。不同小写字母表示差异显著 $(P<0.01)$, 反之表示差异不显著 $(P=0.24)$ 。气候带代号同图 1 。

Fig. 4 The proportion of original Buddhist tree species (a) and Buddhist tree species (b) in different climatic zones. (a) Rank sum test and multiple comparison analysis were used to compare the proportion of original Buddhist tree species among the Buddhist temples in different climatic zones. (b) One-way ANOVA and multiple comparison analysis were used to compare the proportion of Buddhist tree species among the Buddhist temples in different climatic zones. The different letters above the boxes indicate significant difference $(P<0.01)$ and the same letter above the boxes indicate insignificant difference $(P=0.24)$, based on multiple comparisons. The abbreviations of climatic zones are the same as Fig. 1. 


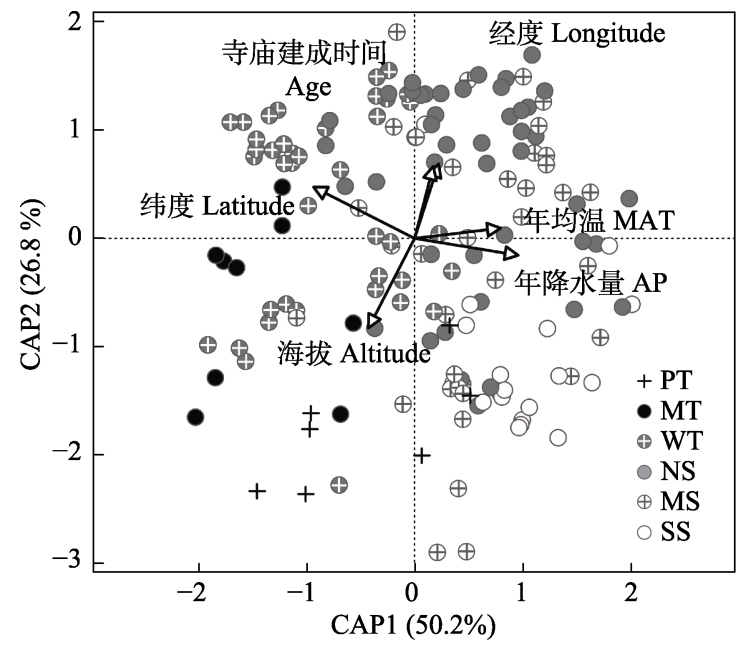

图5 全国佛教树种组成与环境因子间基于辛普森距离的圥 余分析(db-RDA)。圆圈、箭头分别代表寺庙与环境因子, MAT: 年均温; AP: 年降水量, 气候带代号同图1。

Fig. 5 Distance-based redundancy analysis (db-RDA) with Simpson dissimilarity index $\left(\beta_{\mathrm{SIM}}\right)$ depicting the relationship between the selected environmental variables and the variation of Buddhist tree species composition among different climatic zones. Circles and arrows indicate temples and environmental factors respectively. MAT, Mean annual temperature; AP, Annual precipitation. The abbreviations of climatic zones are the same as Fig. 1.

水量、经度、纬度和海拔这几个地理气候因子的影 响较大(图5)。

佛教树种存在树种替代现象，即当原始佛教树 种不适应当地气候条件时, 人们会选择与其形态相 似的乡土植物作为替代佛教树种(附录4)。原始佛教 树种大多分布在中国南部地区寺庙，而替代佛教树 种则分布于北部及高原地区寺庙。随着佛教文化的 相互交流，部分替代佛教树种也传播到南部寺庙， 与原始佛教树种共存(图6)。本研究以“觉悟” “无忧” “涅槃” “花供”4类佛教树种为例(颜晓佳等, 2013), 探明了其在中国的替代情况:

(1)表达“觉悟”意义的佛教树种中, 热带与南亚 热带主要为菩提树; 中亚热带菩提树出现频率下降, 银杏、黄葛树 (Ficus virens var. sublanceolata)、椴树 属树种(Tilia spp.)增加; 北亚热带主要为银杏; 暖 温带菩提树不再出现, 黑弹树(Celtis bungeana)、暴 马丁香(Syringa reticulata subsp. amurensis)成为替 代树种; 中温带和高原温带主要为银杏、暴马丁香 (图6a)。

(2)表达 “无忧” 意义的佛教树种中, 热带与南亚 热带主要为中国无忧花(Saraca dives); 中亚热带和 北亚热带主要为枇杷(Eriobotrya japonica)和垂柳
(Salix babylonica), 中国无忧花不再出现; 暖温带、 中温带和高原温带为垂柳和旱柳(Salix matsudana) (图6b)。

(3)表达“涅槃”意义的佛教树种中, 热带与南亚 热带主要为云南乷罗双和梭罗树属树种(Reevesia spp.); 中亚热带主要为梭罗树属和杪椤属树种 (Alsophila spp.), 云南娑罗双不再出现; 北亚热带和 暖温带为七叶树(Aesculus chinensis)和梧桐属树种 (Firmiana spp.); 中温带和高原温带暂无“涅槃”意 义的佛教树种(图6c)。

(4)用作花供的佛教树种中，热带与南亚热带主 要为鸡蛋花(Plumeria rubra cv. 'Acutifolia')、黄兰 $($ Michelia champaca) 和白兰 $($ Michelia $\times$ alba); 中亚 热带主要为白兰和含笑属树种(Michelia spp.), 鸡蛋 花和黄兰不再出现, 牡丹(Paeonia suffruticosa)和秨 子(Gardenia jasminoides)成为替代树种; 北亚热带 主要为牡丹和栃子; 暖温带为牡丹; 高原温带暂无 花供佛教树种(图6d)。

\section{3 讨论}

\section{1 中国寺庙植物物种组成特征}

佛教植物的物种组成特征体现了佛教文化对 植物物种的选择效应，并反映了佛教文化进入中国 后与中国传统文化的融合。寺庙植物的优势科为萻 薇科、壳斗科和樟科。蓄薇科包含许多常见的水果、 花卉和药材种类, 具有较高的经济与观赏价值(邹 东廷等, 2019)。比如在191座寺庙中出现频率最高的 蓄薇科植物为梅(Armeniaca mume)、月季花(Rosa chinensis)、枇杷和桃(Amygdalus persica), 前两者花 型美丽，后两者果实甘甜，是我国传统花卉与果 树。壳斗科植物种子较大, 淀粉含量高, 在中国具 有很长的食用历史。樟科植物含有芳香类物质, 是 佛教寺庙中制作香料的主要原料。寺庙中出现频率 最高的物种有银杏、木犀、圆柏、侧柏和槐等, 其 中银杏、圆柏和侧柏为佛教树种，而木犀和槐则在 中国传统文化中具有美好内涵(表2)。银杏因其独特 的果实和叶片形态、高大雄伟的树形及长久的寿命, 代替菩提树成为汉传佛教的圣树(关传友, 2007; 陈 凤洁和樊宝敏, 2013; 王早娟, 2017), 其伴随着佛教 文化在中国广泛传播。圆柏和侧柏都是佛教的香料 植物，其根茎叶均为制香的原材料，是佛教“香文 化”的体现(严小青, 2008)。木犀和槐因其吉祥、长寿 

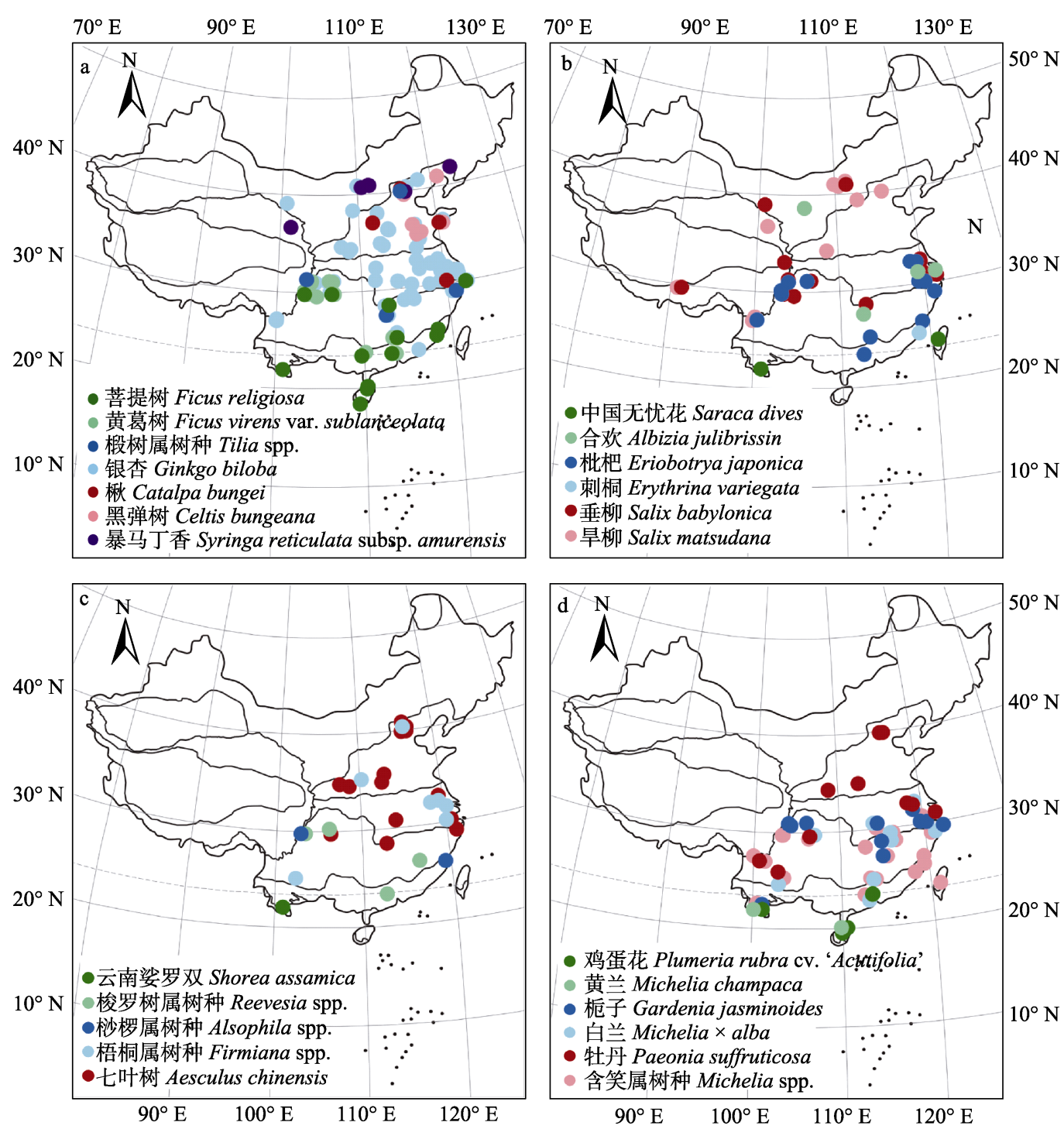

图6 典型原始佛教树种及其替代树种的全国分布。(a)觉悟; (b)无忧; (c)涅槃; (d)花供。

Fig. 6 Distribution of original Buddhist tree species and their alternative tree species. (a) Enlightenment, (b) Worry-free, (c) Nirvana, (d) Offering flowers.

和富贵等美好寓意, 为中国庭院中的常见树种, 佛 教传入后也在佛教寺庙中大量栽培 ${ }^{(1}$ 。

本研究进一步证明了佛教寺庙对植物多样性 的保护作用, 主要表现在以下几个方面: (1)寺庙植 物物种库巨大。本研究在全国191座寺庙中共收集 到树木 1,059 种, 占中国自然分布木本植物总数的 10.7\% (Fang et al, 2011), 占中国城市森林木本植物 总数的 $43.9 \%$ (Yan \& Yang, 2017)。(2)寺庙植物地域 差异较大。大部分树种仅出现在1-2座寺庙中, 物种 组成差异较大。(3)保存了许多乡土植物。191座寺 庙的乡土植物比例平均值为 $63.8 \%$, 这些乡土植物

(1) 袁洁 (2013) 佛教植物文化研究. 硕士学位论文, 浙江农林大学, 杭州.
对当地生物多样性保护及城市绿化物种选择均具 有重要意义(Rozzi, 2013; Qian et al, 2016)。(4)保存 了大量受威胁物种。大部分寺庙中均保存有受威胁 物种, 寺庙是受威胁物种就地保护和迁地保护的绝 佳场所。就地保护以普陀鹅耳杯为典型, 普陀鹅耳 枥自然状态下仅存 1 株，位于普陀佛顶山慧济寺; 迁地保护以水杉为典型，水杉分布于重庆石柱和湖 北利川等地, 四川省宝光寺和安徽省琅躯寺等寺庙 进行了引种栽培。

\section{2 中国佛教树种替代}

佛教树种的分布主要受气候条件限制(图5), 沿纬度梯度从南到北呈现清晰的树种替代现象。原 
始佛教树种多来源于佛教发源地印度(图3a), 以热 带植物为主, 而中国许多地区(尤其是北方及高原 地区)不适宜其生存。这些地区倾向选择与原始佛教 树种形态特征相似的乡土植物作为替代佛教树种 (图4)。以菩提树为例, 菩提树来源于印度北部、巴 基斯坦等地, 属热带季风气候地区植物。受水热条 件限制，菩提树仅分布在中国热带和亚热带寺庙。 在菩提树难以存活或生长不良的地区，则由黄葛 树、椴树属树种、银杏、黑弹树、暴马丁香等作为 替代(图6a)。黄葛树是我国西南地区的乡土植物, 与 菩提树同属，形态相似，是川渝地区的“菩提树”; 南京椴(Tilia miqueliana)又称菩提椴, 叶形与菩提 树叶相似，是我国东部地区的乡土植物，佛教天台 宗祖庭浙江国清寺将南京椴作为“菩提树”, 并将其 与天台宗一起传至日本(史锋厚等, 2012); 暴马丁 香来源我国温带地区，具有较强的耐寒性与耐旱性， 多存在于年降水量与年均温较低的藏传佛教寺庙 内, 世称“西海菩提树” (高川等, 2015)。此外, 本研 究没有考虑佛教派别对寺庙树种组成和树种选择 的影响, 中国的佛教主要分为汉地佛教、南传佛教 和藏传佛教3个派别(宋立道, 2016), 佛教派别的文 化差异和对物种偏好的差异可能会影响到寺庙树 种的组成, 值得进一步深入调查研究。

佛教树种替代现象对部分濒危植物和乡土植 物的传播和保护起到了积极作用。本研究中的 113 种佛教树种中的绝大多数都是来源于国内的替代 佛教树种(98种), 其中19种为珍稀濒危植物, 如银 杏、海南苏铁(Cycas hainanensis)、云南梧桐(Firmiana major)等。在佛教文化的影响下, 这些替代佛 教树种散布于全国大小寺庙中, 得到妥善保护并留 存至今, 是物种遗传多样性的宝库。以云南梧桐为 例, 该物种一度被认为野外灭绝, 近年来才在四川 攀枝花及云南宁蒗和元谋等地陆续发现了其野生 种群(Yang et al, 2018), 而在云南曹溪寺保存有一株 树龄约200年的云南梧桐古树。

\section{3 寺庙园林对区域生物多样性保护和城市绿化 的启示}

在现代化高速发展的背景下, 城市绿化植被出 现均质化现象(Qian et al, 2016), 自然森林景观退化 严重(FAO, 2016)。因此, 有效地利用佛教文化及寺 庙园林资源来维持地区生物多样性和提升城市绿 化水平具有重要意义。首先, 可将寺庙园林作为城
市绿化的物种库。寺庙园林是中国古典园林 3 大类 型之一(仇莉和王丹丹, 2010), 其物种库中不仅包含 有我国古典园林常用植物及一些具特殊文化含义 的树种, 还保存有许多具地域特色的乡土树种(图 2b), 将之作为绿化物种库, 不仅可缓解城市绿化物 种均质化问题，还能减轻生物文化均质化现象 (Rozzi, 2013)。其次，可将寺庙园林中保存的残存自 然植被斑块作为“近自然”群落建设的模板(Miyawaki \& Golley, 1993; 达良俊等, 2004; 卢山等, 2015; 任斌斌等, 2019)。在自然植被破坏殆尽的地区(尤其 是高度城市化区), 寺庙保存下来的自然植被斑块 代表该地区自然植被，能够很好指导当地“近自然” 群落建设(杨永川等, 2007)。最后，可将寺庙园林作 为该地生物多样性保护的热点。寺庙园林本身就是 一个生物多样性宝库，将本地各寺庙联合成整体， 有利于该地生物多样性保护网络的形成。

\section{参考文献}

Aerts R, Van Overtveld K, November E, Wassie A, Abiyu A, Demissew S, Daye DD, Giday K, Haile M, TewoldeBerhan S, Teketay D, Teklehaimanot Z, Binggeli P, Deckers J, Friis I, Gratzer G, Hermy M, Heyn M, Honnay O, Paris M, Sterck FJ, Muys B, Bongers F, Healey JR (2016) Conservation of the Ethiopian church forests: Threats, opportunities and implications for their management. Science of the Total Environment, 551/552, 404-414.

Ai JH (2013) Sacred sites and bio-diversity protection. Journal of Ethnology, 4(2), 69-78. (in Chinese with English abstract) [艾菊红 (2013) 宗教圣境与生物多样性保护. 民族 学刊, 4(2), 69-78.]

Anthwal A, Gupta N, Sharma A, Anthwal S, Kim KH (2010) Conserving biodiversity through traditional beliefs in sacred groves in Uttarakhand Himalaya, India. Resources Conservation and Recycling, 54, 962-971.

Berkes F (2009) Indigenous ways of knowing and the study of environmental change. Journal of the Royal Society of New Zealand, 39, 151-156.

Chen FJ, Fan BM (2013) Influence of Buddhism on ginkgo culture. World Forestry Research, 26(6), 10-14. (in Chinese with English abstract) [陈凤洁, 樊宝敏 (2013) 佛教对银 杏文化的影响. 世界林业研究, 26(6), 10-14.]

Chen YG, Sun GY, Luo JC, Sun JR (2016) Analysis on plant landscape in Famen Temple. China Forest Products Industry, 43(12), 55-58. (in Chinese with English abstract) [陈永贵, 孙广宇, 罗佳晨, 孙景荣 (2016) 浅析法门寺植 物造景艺术. 林产工业, 43(12), 55-58.]

Da LJ, Yang YC, Chen M (2004) The method of ecological greening and its application in the construction of the approaching nature plant community in Shanghai. Chinese 
Landscape Architecture, 20(3), 38-40. (in Chinese with English abstract) [达良俊, 杨永川, 陈鸣 (2004) 生态型 绿化法在上海 “近自然” 群落建设中的应用. 中国园林, 20(3), 38-40.]

Ding YH (2013) Climate in China. Science Press, Beijing. (in Chinese) [丁一汇 (2013) 中国气候. 科学出版社, 北京.]

Dudley N, Parrish JD, Redford KH, Stolton S (2010) The revised IUCN protected area management categories: The debate and ways forward. Oryx, 44, 485-490.

Fang JY, Wang ZH, Tang ZY (2011) Atlas of Woody Plants in China. Springer, Berlin.

FAO (Food and Agriculture Organization of the United Nations) (2016) Forests and Agriculture: Land-Use Challenges and Opportunities. FAO, Rome.

Frascaroli F, Bhagwat S, Guarino R, Chiarucci A, Schmid B (2016) Shrines in central Italy conserve plant diversity and large trees. Ambio, 45, 468-479.

Gao C, Zhang JZ, Shi BS (2015) Preliminary study of cultural connotation of common plants in Beijing temples. Journal of Shanxi Agricultural University (Natural Science Edition), 35, 404-410. (in Chinese with English abstract) [高川, 张 金政, 史宝胜 (2015) 北京市寺庙常用植物文化内涵初 探. 山西农业大学学报(自然科学版), 35, 404-410.]

Guan CY (2007) Discussion on the ginkgo worship culture in China. Agricultural Archaeology, 27(1), 169-173, 280. (in Chinese) [关传友 (2007) 论中国的银杏崇拜文化. 农业 考古, 27(1), 169-173, 280.]

Hu XY, Liu Y, Zhuang XY (2014) Landscape plants and their characteristics in the four Buddhist temple gardens in Guangzhou. Chinese Landscape Architecture, 30(2), 82-86. (in Chinese with English abstract) [胡新月, 刘亚, 庄雪影 (2014) 广州佛教四大从林园林植物及其特色. 中国园林, 30(2), 82-86.]

Jimoh SO, Ikyaagba ET, Alarape AA, Obioha EE, Adeyemi AA (2012) The role of traditional laws and taboos in wildlife conservation in the Oban Hill Sector of Cross River National Park (CRNP), Nigeria. Journal of Human Ecology, 39, 209-219.

Jin HX, Hua HJ (2004) The characteristics of plant landscape in temples. Chinese Landscape Architecture, 20(12), 50-56. (in Chinese with English abstract) [金荷仙, 华海镜 (2004) 寺庙园林植物造景特色. 中国园林, 20(12), 50-56.]

Kowarik I, Buchholz S, van der Lippe M, Seitz B (2016) Biodiversity functions of urban cemeteries: Evidence from one of the largest Jewish cemeteries in Europe. Urban Forestry \& Urban Greening, 19, 68-78.

Li L, Fang CL, Ouyang YF (2011) Plant landscape of temple gardens in Guangxi Province and its comparative analysis between south and north. Journal of Anhui Agricultural Sciences, 39, 496-501. (in Chinese with English abstract) [李林, 方翠莲, 欧阳勇锋 (2011) 广西寺庙园林植物景 观及其南北比较研究. 安徽农业科学, 39, 496-501.]

Liu HM, Xu ZF, Xu YK, Wang JX (2002) Practice of conserving plant diversity through traditional beliefs: A case study in
Xishuangbanna, Southwest China. Biodiversity and Conservation, 11, 705-713.

Lohbeck M, Bongers F, Martinez-Ramos M, Poorter L (2016) The importance of biodiversity and dominance for multiple ecosystem functions in a human-modified tropical landscape. Ecology, 97, 2772-2779.

Lu S, Chen B, Jing J, Zheng Y (2015) Study on the construction of urban close-to-nature plant community in the middle subtropical zone. Chinese Landscape Architecture, 31(6), 91-95. (in Chinese with English abstract) [卢山, 陈波, 敬 婧, 郑烨 (2015) 中亚热带城市近自然人工植物群落构 建研究. 中国园林, 31(6), 91-95.]

Miyawaki A, Golley FB (1993) Forest reconstruction as ecological engineering. Ecological Engineering, 2, 333-345.

Qian S, Qi M, Huang L, Zhao L, Lin D, Yang Y (2016) Biotic homogenization of China's urban greening: A meta-analysis on woody species. Urban Forestry \& Urban Greening, 18, 25-33.

Qin HN, Yang Y, Dong SY, He Q, Jia Y, Zhao LN, Yu SX, Liu HY, Liu B, Yan YH, Xiang JY, Xia NH, Peng H, Li ZY, Zhang ZX, He XJ, Yin LK, Lin YL, Liu QR, Hou YT, Liu Y, Liu QX, Cao W, Li JQ, Chen SL, Jin XH, Gao TG, Chen WL, Ma HY, Geng YY, Jin XF, Chang CY, Jiang H, Cai L, Zang CX, Wu JY, Ye JF, Lai YJ, Liu B, Lin QW, Xue NX (2017) Threatened species list of China's higher plants. Biodiversity Science, 25, 696-744. (in Chinese and in English) [覃海宁, 杨永, 董仕勇, 何强, 贾渝, 赵莉娜, 于胜祥, 刘慧圆, 刘博, 严岳鸿, 向建英, 夏念和, 彭华, 李振宇, 张志翔, 何兴金, 尹林克, 林余霖, 刘全儒, 侯 元同，刘演，刘启新，曹伟，李建强，陈世龙，金效华，高 天刚，陈文俐，马海英，耿玉英，金孝锋，常朝阳，蒋宏， 蔡蕾，枵春奉金，武建勇，叶建飞，赖阳均，刘冰，林秦文， 薛纳新 (2017) 中国高等植物受威胁物种名录. 生物多 样性, 25, 696-744.]

Qiu L, Wang DD (2010) Characteristics of plant landscape of Buddhism monastery garden in China. Journal of Beijing Forestry University (Social Sciences), 9(1), 76-81. (in Chinese with English abstract) [仇莉, 王丹丹 (2010) 中国 佛教寺庙园林植物景观特色. 北京林业大学学报(社会科 学版), 9(1), 76-81.]

Ren BB, Shang R, Li F, Li W, Wang JH, Li G, Liu Q (2019) Close-to-nature plant community construction in urban greenspace of Beijing. Chinese Journal of Ecology, 38, 2911-2917. (in Chinese with English abstract) [任斌斌, 商 茹, 李芳, 李薇, 王建红, 李广, 刘倩 (2019) 北京城市 绿地近自然植物群落构建. 生态学杂志, 38, 2911-2917.]

Rozzi R (2013) Biocultural Ethics: From Biocultural Homogenization Toward Biocultural Conservation. In: Linking Ecology and Ethics for a Changing World Ecology and Ethics (eds Rozzi R, Pickett S, Palmer C, Armesto JJ, Callicott JB), pp. 9-32. Springer, Dordrecht.

Salick J, Amend A, Anderson D, Hoffmeister K, Gunn B, Fang ZD (2007) Tibetan sacred sites conserve old growth trees and cover in the eastern Himalayas. Biodiversity and Con- 
servation, 16, 693-706.

Shi FH, Shen YB, Shi JS (2012) Protection, development and utilization of Tilia miqueliana resources. Journal of Forestry Engineering, 26(3), 11-14. (in Chinese) [史锋厚, 沈永宝, 施季森 (2012) 南京椴资源的保护和开发利用. 林业工 程学报, 26(3), 11-14.]

Song LD (2016) The historical status and social significance of Theravada Buddhism. The World Religious Cultures, 23(2), 41-48, 158. (in Chinese with English abstract) [宋立道 (2016) 南传佛教的历史地位与现实社会意义. 世界宗教 文化, 23(2), 41-48, 158.]

Tucker ME, Williams DR (translated by He ZY, Yan Y, Qin J) (2008) Buddhism and Ecology: The Interconnection of Dharma and Deeds. Jiangsu Education Publishing House, Nanjing. (in Chinese) [何则阴, 间艳, 覃江等 (译) (2008) 佛 教与生态. 江苏教育出版社, 南京.]

Wang ZJ (2017) The Plants of Chang'an Buddhist Temple in Tang Dynasty from the Perspective of Ecological Culture. Xidian University Press, Xi'an. (in Chinese) [王早娟 (2017) 生态文化视野下的唐代长安佛寺植物. 西安电子 科技大学出版社, 西安.]

Yan PB, Yang J (2017) Species diversity of urban forests in China. Urban Forestry \& Urban Greening, 28, 160-166.

Yan XJ, Zhou YL, Li SS (2013) Common plants in Buddhist temples. Bulletin of Biology, 48(11), 7-11. (in Chinese) [颜 晓佳, 周云龙, 李韶山 (2013) 佛教寺庙常见植物. 生物 学通报, 48(11), 7-11.]

Yan XQ (2008) The Study of Aromatic Plant Production, Utilization and Trade in Ancient China. PhD dissertation, Nanjing Agricultural University, Nanjing. (in Chinese with English abstract) [严小青 (2008) 中国古代植物香料生产、 利用与贸易研究. 博士学位论文, 南京农业大学, 南京.]

Yang J, Chen G, Sun WB (2018) Conserving Firmiana major, a tree species endemic to China. Oryx, 52, 211.

Yang LX, Pei SJ, Zhang Y (2019) Action research on Tibetan sacred nature sites (SNS) conservation in Tibetan community in NW Yunnan. Biodiversity Science, 27, 749-757. (in
Chinese with English abstract) [杨立新, 裴盛基, 张宇 (2019) 滇西北藏区自然圣境与传统文化驱动下的生物多 样性保护. 生物多样性, 27, 749-757.]

Yang YC, Yuan XZ, Li BZ, Sun R, Wang Q (2007) Characteristics and significance of the remnant evergreen broad-leaved forest in the urban area of Chongqing, China. Biodiversity Science, 15, 247-256. (in Chinese with English abstract) [杨永川, 袁兴中, 李百战, 孙荣, 王强 (2007) 重庆都市区残存常绿阔叶林的群落特征及其意义. 生物 多样性, 15, 247-256.]

Ye HY, Xie CP, Tang GG (2009) Study on plant community feature in Nanjing temple gardens. Journal of Anhui Agricultural Sciences, 37, 17735-17737. (in Chinese with English abstract) [叶海跃, 谢春平, 汤庚国 (2009) 南京 地区寺庙园林植物群落特征研究. 安徽农业科学, 37, 17735-17737.]

Zhao YP, Fan G, Yin PP, Sun S, Li N, Hong XN, Hu G, Zhang H, Zhang FM, Han JD, Hao YJ, Xu QW, Yang XW, Xia WJ, Chen WB, Lin HY, Zhang R, Chen J, Zheng XM, Lee SMY, Lee J, Uehara K, Wang JA, Yang HM, Fu CX, Liu X, $\mathrm{Xu} \mathrm{X,} \mathrm{Ge} \mathrm{S} \mathrm{(2019)} \mathrm{Resequencing} 545$ ginkgo genomes across the world reveals the evolutionary history of the living fossil. Nature Communications, 10, 1-10.

Zong H, Zhang N (2013) Research progress of traditional temple garden in China. Journal of Anhui Agricultural Sciences, 41, 3009-3011. (in Chinese with English abstract) [宗桦, 张楠 (2013) 中国传统寺观园林研究进展综述. 安徽农业科学, 41, 3009-3011.]

Zou DT, Wang QG, Luo A, Wang ZH (2019) Species richness patterns and resource plant conservation assessments of Rosaceae in China. Chinese Journal of Plant Ecology, 43, 1-15. (in Chinese with English abstract) [邹东廷, 王庆刚, 罗奥, 王志恒 (2019) 中国蓄薇科植物多样性格局及其 资源植物保护现状. 植物生态学报, 43, 1-15.]

(责任编委: 杨军 责任编辑: 黄祥忠)

\section{附录 Supplementary Material}

\section{附录1 本研究分析的191座寺庙树种名录数据来源}

Appendix 1 Data sources of temple tree species list 191 Buddhist temples analyzed in this study http://www.biodiversity-science.net/fileup/PDF/2019392-1.pdf

附录2 本研究分析的191座佛教寺庙的详细信息

Appendix 2 Details of 191 Buddhist temples analyzed in this study http://www.biodiversity-science.net/fileup/PDF/2019392-2.pdf

附录3 佛教树种鉴定参考文献

Appendix 3 References for identifying Buddhist tree species http://www.biodiversity-science.net/fileup/PDF/2019392-3.pdf

附录4 中国寺庙中常见的原始佛教树种及其在中国的替代佛教树种

Appendix 4 Original Buddhist tree species and their alternative Buddhist tree species in China http://www.biodiversity-science.net/fileup/PDF/2019392-4.pdf 
王新阳, 靳程, 黄力, 周礼华, 郑明铭, 钱深华, 杨永川. 中国佛教寺庙植物多样性和佛教树种替代. 生物多

样性, 2020, 28 (6):668-677. http://www.biodiversity-science.net/CN/10.17520/biods.2019392

\section{附录1 本研究分析的191座寺庙树种名录数据来源}

Appendix 1 Data sources of temple tree species list 191 Buddhist temples analyzed in this study

\begin{tabular}{|c|c|c|}
\hline 序号 No. & 类型 Type & 文献资料 References \\
\hline 1 & 学位论文 & 郡燕 (2007) 镇江市寺庙园林植物景观研究. 硕士学位论文, 南京林业大学, 南京. \\
\hline 2 & 学位论文 & 叶海跃 (2007) 南京地区寺庙园林植物景观研究. 硕士学位论文, 南京林业大学, 南京. \\
\hline 3 & 学位论文 & 董冬 (2008) 九华山风景区古树名木的群落学特征与景观价值研究. 硕士学位论文, 安徽农业大学, 合肥. \\
\hline 4 & 学位论文 & 刘枫 (2008) 福州市寺庙园林研究. 硕士学位论文, 福建农林大学, 福州. \\
\hline 5 & 学位论文 & 李云巧 (2009) 丽江市寺庙园林植物景观研究. 硕士学位论文, 四川农业大学, 雅安. \\
\hline 6 & 学位论文 & 邹文芳 (2009) 植物造景在成都市寺观园林中的应用研究. 硕士学位论文, 西南交通大学, 成都. \\
\hline 7 & 学位论文 & 汤露 (2009) 成都市主要寺观园林植物群落的研究. 硕士学位论文, 四川农业大学, 雅安. \\
\hline 8 & 学位论文 & 王小玲 (2010) 中国宗教园林植物景观营造初探. 硕士学位论文, 北京林业大学, 北京. \\
\hline 9 & 学位论文 & 苏婕 (2010) 青岛市宗教园林历史文化内涵及环境特征研究. 硕士学位论文, 山东农业大学, 泰安. \\
\hline 10 & 学位论文 & 杨茹 (2011) 普陀山寺庙植物景观研究. 硕士学位论文, 浙江农林大学, 杭州. \\
\hline 11 & 学位论文 & 何小凤 (2011) 泉州寺庙园林研究. 硕士学位论文, 福建农林大学, 福州. \\
\hline 12 & 学位论文 & 陈静宜 (2011) 上海地区佛寺空间特征研究. 硕士学位论文, 上海交通大学, 上海. \\
\hline 13 & 学位论文 & 朱琳 (2012) 杭州市宗教园林植物景观研究. 硕士学位论文, 浙江农林大学, 杭州. \\
\hline 14 & 学位论文 & 魏彩霞 (2012) 杭州市寺观园林研究. 硕士学位论文, 浙江农林大学, 杭州. \\
\hline 15 & 学位论文 & 陈蓉 (2012) 现代佛寺园林景观的营造. 硕士学位论文, 南京林业大学, 南京. \\
\hline 16 & 学位论文 & 李娜 (2013) 呼和浩特市与包头市藏传佛教寺庙园林环境研究. 硕士学位论文, 内蒙古农业大学, 呼和浩特. \\
\hline 17 & 学位论文 & 邓磷曦 (2013) 国清寺寺庙园林植物造景研究. 硕士学位论文, 浙江农林大学, 杭州. \\
\hline 18 & 学位论文 & 王珂歆 (2013) 四川寺庙园林景观结构及其发展研究一一以峨眉大佛禅院为例. 硕士学位论文, 四川农业大学, 成都. \\
\hline 19 & 学位论文 & $\begin{array}{l}\text { 吴兰珊 (2014) 山岳风景区寺庙佛教文化景观保护与利用研究一一以云岩寺风景区为例. 硕士学位论文, 湖南农业科技 } \\
\text { 大学, 长沙. }\end{array}$ \\
\hline 20 & 学位论文 & 董旭 (2015) 承德普陀宗乘之庙历史与建筑研究. 博士学位论文, 河北师范大学, 石家庄. \\
\hline 21 & 学位论文 & 高川 (2015) 北京地区佛教寺院植物景观特征研究. 硕士学位论文, 河北农业大学, 保定. \\
\hline 22 & 学位论文 & 赵伟平 (2016) 基于佛教生态观的长沙开福寺园林景观改造设计. 硕士学位论文, 东北农业大学, 哈尔滨. \\
\hline 23 & 学位论文 & 郭利凡 (2016) 河南安阳地区寺观园林研究. 硕士学位论文, 河南农业大学, 郑州. \\
\hline 24 & 学位论文 & 陈茜 (2016) 西安户县草堂寺景观设计研究. 硕士学位论文, 长安大学, 西安. \\
\hline 25 & 学位论文 & 宋昌吉 (2016) 海南佛寺园林景观意境营造分析. 硕士学位论文, 海南大学, 海口. \\
\hline 26 & 学位论文 & 汤妍 (2017) 沈阳地区寺庙景观环境研究. 硕士学位论文, 沈阳建筑大学, 沈阳. \\
\hline 27 & 期刊文献 & 华明夫 (1995) 古寺名木话青檀. 绿化与生活 2(1), 18-19. \\
\hline 28 & 期刊文献 & $\begin{array}{l}\text { Liu HM, Xu ZF, Xu YK, Wang JX (2002) Practice of conserving plant diversity through traditional beliefs: A case study in } \\
\text { Xishuangbanna, Southwest China. Biodiversity \& Conservation, 11, 705-713. }\end{array}$ \\
\hline 29 & 期刊文献 & 汪永平，吕伟娅 (2002) 藏式建筑与园林艺术的杰作——罗布林卡. 南京工业大学学报(社会科学版), 4(1), 75-79. \\
\hline 30 & 期刊文献 & 唐闻 (2003) 历史在这里延续——探访武汉古树名木. 今日湖北, 4(11), 36-37. \\
\hline 31 & 期刊文献 & 魏雷, 王玏, 高翅 (2007) 幽深清远的诗意空间——论武汉宝通禅寺园林空间艺术. 华中农业大学学报, 9(3), 137-140. \\
\hline 32 & 期刊文献 & 马越 (2008) 西安曲江园林风景区古今植物景观分析. 西北林学院学报, 23(6), 218-222. \\
\hline 33 & 期刊文献 & 关传友 (2008) 安徽寺院古林的探析. 农业考古, (4), 218-220. \\
\hline 34 & 期刊文献 & 马中举, 王正神 (2009) 川西寺庙园林植物造景探析. 北方园艺, 33(2), 216-219. \\
\hline 35 & 期刊文献 & 郑忠, 刘海 (2010) 普陀山普济寺植物景观效果分析. 现代农业科技, (6), 198-199. \\
\hline 36 & 期刊文献 & 曹东平，叶晓梅 (2011) 浅析榆林寺庙园林. 内蒙古林业调查设计, 18(3), 110-112. \\
\hline 37 & 期刊文献 & 张颖,商铁林 (2011) 陕北寺庙园林景观营造探析. 安徽农业科学, 39, 13014-13016. \\
\hline 38 & 期刊文献 & 方鹏, 武斌 (2013) 龙塔公园寺庙园林植物景观的设计与营造. 南方农业, 7(6), 15-16. \\
\hline 39 & 期刊文献 & 黄萌, 高丽琴, 熊宇, 钱萍, 季春峰 (2013) 豫章名寺一一南昌佑民寺植物配置研究. 江西林业科技, 41(1), 60-62. \\
\hline 40 & 期刊文献 & 张树生 (2013) 避暑山庄周围寺庙园林艺术特色及园林绿化探索. 绿色科技, 4(1), 156-158. \\
\hline 41 & 期刊文献 & 赵杨迪, 刘洪坤, 任为, 文虹冰 (2014) 浅论南充市清泉寺宗教景观营造. 广东园林, 36(6), 53-56. \\
\hline 42 & 期刊文献 & 王爱民, 张译天 (2014) 都市观音文化与寺庙园林一一以上海东海新观音寺为例. 中国名城, 7(8), 45-51. \\
\hline 43 & 期刊文献 & 蔡璐, 刘明新, 贝锦, 何晶鸿, 曹捷 (2014) 长沙古寺庙生态景观调查研究. 合作经济与科技, 21(20), 32-33. \\
\hline
\end{tabular}




\begin{tabular}{|c|c|c|}
\hline 序号 No. & 类型 Type & 文献资料 References \\
\hline 44 & 期刊文献 & 赵杨迪, 刘洪坤, 任为, 文虹冰 (2015) 凌云山白山寺园林植物造景分析及优化建议. 绿色科技, 6(8), 66-68. \\
\hline 45 & 期刊文献 & 周莞, 刘纯青 (2015) 探析寺庙园林的地域性特点及保护意见一一以宜春三大名寺为例. 知识窗(教师版), 7(8), 44-45. \\
\hline 46 & 期刊文献 & 陈永贵, 孙广宇, 罗佳晨, 孙景荣 (2016) 浅析法门寺植物造景艺术. 林产工业, 43(12), 55-58. \\
\hline 47 & 期刊文献 & 邹林海, 陈宇 (2017) 扬州市寺庙园林景观现状调查及保护建议. 黑龙江农业科学, (1), 90-94. \\
\hline 48 & 书籍 & 郭季则 (1982) 南岳古树名木调查. 南岳树木园, 衡阳. \\
\hline 49 & 书籍 & 李永芳, 于志民, 周仁吉, 王博兰, 施海 (1995) 北京郊区古树名木志. 中国林业出版社, 北京. \\
\hline 50 & 官方资料 & 中国科学院植物研究所 (2008) 中国植物图像库. http://ppbc.iplant.cn/search (accessed on 2018-03-30) \\
\hline 51 & 官方资料 & 中国科学院植物研究所 (2016) 国家标本平台 http://www.nsii.org.cn/2017/query.php (accessed on 2018-11-20) \\
\hline 52 & 官方资料 & 广东省林业局 (2017) 广东省古树名木信息管理系统. http://121.33.231.227:8070/Default.aspx (accessed on 2018-03-01) \\
\hline 53 & 官方资料 & 广西壮族自治区林业科学研究院 (2017) 广西古树名木系统. http://221.7.254.107:8086/ (accessed on 2018-03-05) \\
\hline 54 & 官方资料 & $\begin{array}{l}\text { 杭州市林业局 (2016) 临安市古树名木汇总表. http://www.linan.gov.cn/art/2016/9/17/art_1367676_11448667.html (accessed } \\
\text { on 2018-04-24) }\end{array}$ \\
\hline 55 & 官方资料 & $\begin{array}{l}\text { 扬州市绿化委员会 (2007) 扬州市古树名木汇编. https://max.book118.com/html/2017/0514/106791737.shtm (accessed on } \\
\text { 2018-04-14) }\end{array}$ \\
\hline 56 & 官方资料 & $\begin{array}{l}\text { 苏州市园林和绿化管理局 (2011) 苏州市古树名木一览表(第一批). } \\
\text { http://www.suzhou.gov.cn/bmdw/sylhlhglj/ggfw_711/bmfw_-12/ggsy_714/cslh_715/201110/t20111011_23652.shtml } \\
\text { (accessed on 2018-03-13) }\end{array}$ \\
\hline 57 & 官方资料 & 安徽省绿化委员会 (2011) 安徽省古树名木名录. https://www.docin.com/p-373524940.html (accessed on 2018-04-02) \\
\hline 58 & 官方资料 & $\begin{array}{l}\text { 甘肃省林业厅 (2015) 甘肃省古树名木查询平台. http://lycy.gansu.gov.cn/content/2015-11/40002.html（accessed on 2018- } \\
04-17)\end{array}$ \\
\hline 59 & 官方资料 & $\begin{array}{l}\text { 中国城市规划设计研究院 (2017) 隆中风景区古树名木一览表. } \\
\text { https://max.book118.com/html/2018/1112/6235034243001230.shtm (accessed on 2018-04-14) }\end{array}$ \\
\hline 60 & 网络资料 & 豆丁网 (2011) 昆明地区古树名木一览表. https://www.docin.com/p-1399295372.html (accessed on 2018-03-30) \\
\hline 61 & 官方资料 & $\begin{array}{l}\text { 苏州市园林和绿化管理局 (2011) 苏州市古树名木一览表(第二批). } \\
\text { http://www.suzhou.gov.cn/bmdw/sylhlhglj/ggfw_711/bmfw_712/ggsy_714/cslh_715/201110/t20111011_23653.shtml (accessed } \\
\text { on 2018-03-13) }\end{array}$ \\
\hline 62 & 网络资料 & $\begin{array}{l}\text { 三秦游网 (1986) 西安市城区及风景名胜区古树名木调查统计表. } \\
\text { http://www.sanqinyou.com/shaanxi/info/131517421215623.html (accessed on 2018-03-29) }\end{array}$ \\
\hline 63 & 网络资料 & $\begin{array}{l}\text { 百度文库 (2012) 庆云寺名录. https://wenku.baidu.com/view/273f0b8f84868762caaed548.html?from=search (accessed on } \\
\text { 2018-03-19) }\end{array}$ \\
\hline 64 & 网络资料 & $\begin{array}{l}\text { 杜鹏 (2008) 人文文化对园林植物配置的影响——以归元寺为例. http://blog.sina.com.cn/s/blog_56b5c87b0102v9x2.html } \\
\text { (accessed on 2018-03-30) }\end{array}$ \\
\hline 65 & 网络资讯 & 百度文库 (2014) 张掖大佛寺简介. https://wenku.baidu.com/view/cebcd27e33687e21ae45a929.html (accessed on 2018-03-30) \\
\hline 66 & 网络资讯 & $\begin{array}{l}\text { 百度百科 (2017) 县华寺. https://baike.baidu.com/item/\%E6\%98\%99\%E5\%8D\%8E\%E5\%AF\%BA/3313462?fr=aladdin } \\
\text { (accessed on 2018-03-30) }\end{array}$ \\
\hline 67 & 网络资讯 & 天涯社区网 (2005) 图说自贡——旅游景点篇. http://bbs.tianya.cn/post-285-694-1.shtml (accessed on 2018-03-30) \\
\hline 68 & 网络资讯 & $\begin{array}{l}\text { 中国园林网 (2012) 太原万柏林区龙泉寺周边开始绿化改造. http://news.yuanlin.com/View/108851/1.htm (accessed on 2018- } \\
\text { 03-30) }\end{array}$ \\
\hline 69 & 网络资讯 & $\begin{array}{l}\text { 中国园林网 (2012) 江苏: } 20 \text { 日左右是最佳赏秋时节，惠山寺红叶银杏最佳. http://news.yuanlin.com/View/127546/1.htm } \\
\text { (accessed on 2018-03-30) }\end{array}$ \\
\hline 70 & 网络资讯 & $\begin{array}{l}\text { 佛教导航网 (2012) 和平寺-昌平-北京寺院. http://www.fjdh.cn/ffzt/fjhy/ahsy2012/08/093415185373.html (accessed on 2018- } \\
\text { 03-30) }\end{array}$ \\
\hline 71 & 网络资讯 & 大江论坛网 (2013) 丛林福地三缘寺. http://bbs.jxnews.com.cn/thread-1772767-1-1.html (accessed on 2018-03-30) \\
\hline 72 & 网络资讯 & $\begin{array}{l}\text { 新浪博客网 (2013) 海南游: 南山寺的植物. http://blog.sina.com.cn/s/blog_6d01e2bf0102e4cy.html\#cmt_5147F921- } \\
\text { 7F000001-6D02F377-7F8-8A0 (accessed on 2018-03-30) }\end{array}$ \\
\hline 73 & 网络资讯 & 新浪博客网 (2013) 慈云寺听说佛道. http://blog.sina.com.cn/s/blog_5b172f4d0101ac9s.html (accessed on 2018-03-30) \\
\hline 74 & 网络资讯 & 新浪博客网 (2016) 香泉映月. http://blog.sina.com.cn/s/blog_660552000102we9i.html (accessed on 2018-03-30) \\
\hline 75 & 网络资讯 & 新浪博客网 (2016) 秋游北普陀山. http://blog.sina.com.cn/s/blog_4ba357ca0102w5v7.html (accessed on 2018-03-30) \\
\hline 76 & 网络资讯 & $\begin{array}{l}\text { 山西省文物技术中心 (2016) 传统建筑的传承——介休回鸾寺之大雄宝殿的法式特征勘察分析. } \\
\text { https://wenku.baidu.com/view/c9b4420f9e314332386893bb.html (accessed on 2018-03-30) }\end{array}$ \\
\hline 77 & 网络资讯 & $\begin{array}{l}\text { 新浪博客网 (2017) 黄梅四祖寺: 千年古柏藏祖意, 蜡梅雪后露禅机. http://blog.sina.com.cn/s/blog_7249623e0102x1hq.html } \\
\text { (accessed on 2018-03-30) }\end{array}$ \\
\hline 78 & 网络资讯 & $\begin{array}{l}\text { 寿县人民政府 (2017) 报恩寺的树. http://www.shouxian.gov.cn/content/detail/565e3c80592c201729dff9fd.html (accessed on } \\
\text { 2018-03-30) }\end{array}$ \\
\hline 79 & 网络资讯 & 新浪博客网 (2017) 辽宁义县奉国寺(国一). http://blog.sina.com.cn/s/blog_4a154a510102xi75.html (accessed on 2018-03-30) \\
\hline 80 & 网络资讯 & $\begin{array}{l}\text { 新浪博客网 (2017) 黄梅五祖寺: 一树一菩提 http://blog.sina.com.cn/s/blog_7249623e0102x1hp.html (accessed on 2018-03- } \\
\text { 30) }\end{array}$ \\
\hline 81 & 网络资讯 & $\begin{array}{l}\text { 新浪博客网 (2017) 当阳玉泉寺: 荆楚丛林之冠. http://blog.sina.com.cn/s/blog_7249623e0102x1jd.html (accessed on 2018- } \\
\text { 03-30) }\end{array}$ \\
\hline
\end{tabular}


王新阳, 靳程, 黄力, 周礼华, 郑明铭, 钱深华, 杨永川. 中国佛教寺庙植物多样性和佛教树种替代. 生物多 样性, 2020, 28 (6):668-677. http://www.biodiversity-science.net/CN/10.17520/biods.2019392

\begin{tabular}{|c|c|c|}
\hline 序号 No. & 类型 Type & 文献资料 References \\
\hline 82 & 网络资讯 & $\begin{array}{l}\text { 新浪博客网 (2017) 海南澄迈盈滨半岛禅林永庆寺. http://blog.sina.com.cn/s/blog_60f13e6d0102xi9q.html (accessed on 2018- } \\
\text { 03-30) }\end{array}$ \\
\hline 83 & 网络资讯 & 简书网 (2017) 洛阳白马寺. https://www.jianshu.com/p/2748081d29dc (accessed on 2018-03-30) \\
\hline
\end{tabular}


王新阳, 靳程, 黄力, 周礼华, 郑明铭, 钱深华, 杨永川. 中国佛教寺庙植物多样性和佛教树种替代. 生物多 样性, 2020, 28 (6):668-677. http://www.biodiversity-science.net/CN/10.17520/biods.2019392

附录2 本研究分析的191座佛教寺庙的详细信息

Appendix 2 Details of 191 Buddhist temples analyzed in this study

\begin{tabular}{|c|c|c|c|c|c|c|}
\hline $\begin{array}{l}\text { 序号 } \\
\text { No. }\end{array}$ & $\begin{array}{l}\text { 寺庙 } \\
\text { Temple }\end{array}$ & $\begin{array}{l}\text { 地址 } \\
\text { Address }\end{array}$ & $\begin{array}{l}\text { 经度 } \\
\text { Longitude (E) }\end{array}$ & $\begin{array}{l}\text { 纬度 } \\
\text { Latitude (N) }\end{array}$ & $\begin{array}{l}\text { 寺庙建成年份 } \\
\text { Year of temple } \\
\text { construction }\end{array}$ & $\begin{array}{l}\text { 附录 } 1 \text { 中参考文献序 } \\
\text { 号 No. of references } \\
\text { in Appendix } 1\end{array}$ \\
\hline 1 & 琅躯寺 & 安徽省滁州市琅躯区琅躯山旅游区 & $32.27^{\circ}$ & $118.28^{\circ}$ & 768 & 33,50 \\
\hline 2 & 西庐寺 & 安徽省合肥市肥西县紫蓬山 & $31.71^{\circ}$ & $117.01^{\circ}$ & 180 & 33 \\
\hline 3 & 报恩寺 & 安徽省淮南市寿县 & $32.58^{\circ}$ & $116.79^{\circ}$ & 638 & 78 \\
\hline 4 & 云谷寺 & 安徽省黄山市黄山风景区 & $30.12^{\circ}$ & $118.19^{\circ}$ & 1597 & 51,57 \\
\hline 5 & 甘露寺 & 安徽省青阳县九华山风景区 & $30.49^{\circ}$ & $117.80^{\circ}$ & 1667 & 3,33 \\
\hline 6 & 通慧寺 & 安徽省青阳县九华山风景区 & $30.48^{\circ}$ & $117.80^{\circ}$ & 629 & 3, 51 \\
\hline 7 & 心愿庵 & 安徽省青阳县九华山风景区 & $30.47^{\circ}$ & $117.81^{\circ}$ & 1929 & 3 \\
\hline 8 & 祇园寺 & 安徽省青阳县九华山风景区 & $30.48^{\circ}$ & $117.80^{\circ}$ & 1796 & 3 \\
\hline 9 & 青阳天台寺 & 安徽省青阳县九华山天台峰顶 & $30.46^{\circ}$ & $117.83^{\circ}$ & 1368 & 51 \\
\hline 10 & 瑞云寺 & 安徽省宿州市萧县皇藏峪国家森林公园 & $34.02^{\circ}$ & $117.05^{\circ}$ & 541 & 33 \\
\hline 11 & 秀峰寺 & 北京海淀区鹑峰山 & $40.06^{\circ}$ & $116.10^{\circ}$ & 1511 & 49 \\
\hline 12 & 和平寺 & 北京市昌平区桃洼乡花塔村 & $40.22^{\circ}$ & 116.06 & 623 & 70 \\
\hline 13 & 雍和宫 & 北京市东城区雍和宫大街 12 号 & $39.95^{\circ}$ & 116.42 & 1694 & 21 \\
\hline 14 & 卧佛寺 & 北京市海淀区北京植物园 & $40.01^{\circ}$ & $116.21^{\circ}$ & 630 & 21,51 \\
\hline 15 & 万寿寺 & 北京市海淀区高梁河广源闸 & $39.95^{\circ}$ & $116.31^{\circ}$ & 1577 & 21,50 \\
\hline 16 & 碧云寺 & 北京市海淀区香山公园 & $40.00^{\circ}$ & $116.19^{\circ}$ & 1331 & 21,50 \\
\hline 17 & 大觉寺 & 北京市海淀区阳台山麓 & $40.05^{\circ}$ & $116.11^{\circ}$ & 1068 & 21,50 \\
\hline 18 & 红螺寺 & 北京市怀柔区红螺山 & $40.37^{\circ}$ & $116.63^{\circ}$ & 338 & 50 \\
\hline 19 & 潭柘寺 & 北京市门头沟区潭柘寺镇 & $39.90^{\circ}$ & $116.03^{\circ}$ & 316 & 21,50 \\
\hline 20 & 戒台寺 & 北京市门头沟区永定镇 & $39.87^{\circ}$ & $116.09^{\circ}$ & 622 & 21 \\
\hline 21 & 灵光寺 & 北京市石景山区八大处公园 & $39.96^{\circ}$ & $116.18^{\circ}$ & 773 & 21 \\
\hline 22 & 香界寺 & 北京市石景山区八大处公园 & $39.96^{\circ}$ & $116.18^{\circ}$ & 758 & 21 \\
\hline 23 & 永安寺 & 北京市西城区北海公园 & $39.92^{\circ}$ & $116.39^{\circ}$ & 1651 & 21 \\
\hline 24 & 法源寺 & 北京市西城区法源寺前街 7 号 & $39.88^{\circ}$ & $116.37^{\circ}$ & 645 & 21,50 \\
\hline 25 & 广济寺 & 北京市西城区阜成门内大街 25 号 & $39.92^{\circ}$ & $116.37^{\circ}$ & 1175 & 21 \\
\hline 26 & 广化寺 & 北京市西城区鸦儿胡同 31 号 & $39.94^{\circ}$ & $116.39^{\circ}$ & 1342 & 21 \\
\hline 27 & 缙云寺 & 重庆市北碚区缙云山 & $29.84^{\circ}$ & $106.40^{\circ}$ & 423 & 50,51 \\
\hline 28 & 龙头寺 & 重庆市渝北区龙塔街道龙头寺路 86 号 & $29.59^{\circ}$ & $106.54^{\circ}$ & 1506 & 38 \\
\hline 29 & 涌泉寺 & 福建省福州市晋安区鼓山镇鼓山风景名胜区 & $26.06^{\circ}$ & $119.40^{\circ}$ & 908 & 4 \\
\hline 30 & 林阳寺 & 福建省福州市晋安区寿山乡 & $26.21^{\circ}$ & $119.32^{\circ}$ & 936 & 4,50 \\
\hline 31 & 灵峰寺 & 福建省宁德市福鼎市冷城村西门外 & $27.14^{\circ}$ & $120.24^{\circ}$ & 990 & 51 \\
\hline 32 & 支提寺 & 福建省宁德市支提山 & $26.81^{\circ}$ & $119.39^{\circ}$ & 971 & 50 \\
\hline 33 & 开元寺 & 福建省泉州市鲤城区西街 176 号 & $25.32^{\circ}$ & $118.29^{\circ}$ & 686 & 11,50 \\
\hline 34 & 南普陀寺 & 福建省厦门市思明区思明南路 515 号 & $24.72^{\circ}$ & $118.15^{\circ}$ & 960 & 50,51 \\
\hline 35 & 云盖寺 & 福建省漳州市龙海市浮宫镇 & $24.37^{\circ}$ & $117.95^{\circ}$ & 1050 & 50 \\
\hline 36 & 香泉寺 & 甘肃省陇南市两当县 & $33.40^{\circ}$ & $104.92^{\circ}$ & 1120 & 58,74 \\
\hline 37 & 云崖寺 & 甘肃省平凉市庄浪县云崖寺国家森林公园 & $35.20^{\circ}$ & $106.24^{\circ}$ & 400 & 51 \\
\hline 38 & 天水甘泉寺 & 甘肃省天水市麦积区甘泉镇 & $34.45^{\circ}$ & $105.94^{\circ}$ & 700 & 58 \\
\hline 39 & 南郭寺 & 甘肃省天水市南郭路 39 号 & $34.56^{\circ}$ & $105.75^{\circ}$ & 405 & 58 \\
\hline 40 & 张掖大佛寺 & 甘肃省张掖市甘州区民主西街 & $38.80^{\circ}$ & $101.03^{\circ}$ & 425 & 65 \\
\hline 41 & 光孝寺 & 广东省广州市越秀区光孝路 109 号 & $23.13^{\circ}$ & $113.26^{\circ}$ & 235 & 52 \\
\hline 42 & 公坑寺 & 广东省江门市棠下镇龙舟山森林公园 & $22.64^{\circ}$ & $113.02^{\circ}$ & 1300 & 52 \\
\hline 43 & 石灵寺 & 广东省揭阳市揭西县钱坑镇 & $23.41^{\circ}$ & $116.00^{\circ}$ & 1731 & 52 \\
\hline
\end{tabular}


王新阳, 靳程, 黄力, 周礼华, 郑明铭, 钱深华, 杨永川. 中国佛教寺庙植物多样性和佛教树种替代. 生物多 样性, 2020, 28 (6):668-677. http://www.biodiversity-science.net/CN/10.17520/biods.2019392

\begin{tabular}{|c|c|c|c|c|c|c|}
\hline $\begin{array}{l}\text { 序号 } \\
\text { No. }\end{array}$ & $\begin{array}{l}\text { 寺庙 } \\
\text { Temple }\end{array}$ & $\begin{array}{l}\text { 地址 } \\
\text { Address }\end{array}$ & $\begin{array}{l}\text { 经度 } \\
\text { Longitude (E) }\end{array}$ & $\begin{array}{l}\text { 纬度 } \\
\text { Latitude (N) }\end{array}$ & $\begin{array}{l}\text { 寺庙建成年份 } \\
\text { Year of temple } \\
\text { construction }\end{array}$ & $\begin{array}{l}\text { 附录 } 1 \text { 中参考文献序 } \\
\text { 佫. of references } \\
\text { in Appendix } 1\end{array}$ \\
\hline 44 & 南华寺 & 广东省韶关市曲江区马 & $24.65^{\circ}$ & $113.64^{\circ}$ & 502 & 50,52 \\
\hline 45 & 大觉禅寺 & 广东省韶关市乳源瑶族自治县 & $24.81^{\circ}$ & $113.31^{\circ}$ & 923 & 50 \\
\hline 46 & 白云寺 & 广东省肇庆市鼎湖山 & $23.16^{\circ}$ & $112.53^{\circ}$ & 678 & 51 \\
\hline 47 & 庆云寺 & 广东省肇庆市鼎湖山天溪山谷 & $23.17^{\circ}$ & $112.55^{\circ}$ & 1636 & 50,63 \\
\hline 48 & 贵港龙华寺 & 广西贵港市桂平市西山镇西山风景名胜区 & $23.40^{\circ}$ & $110.06^{\circ}$ & 960 & 53 \\
\hline 49 & 贵港南山寺 & 广西贵港市南山公园 & $23.05^{\circ}$ & $109.62^{\circ}$ & 989 & 53 \\
\hline 50 & 雷公田寺 & 广西桂林市两水苗族乡塘洞村猫儿山雷公岩 & $25.24^{\circ}$ & $110.20^{\circ}$ & 1368 & 53 \\
\hline 51 & 湘山寺 & 广西桂林市全州县桂黄中路 66 号 & $25.93^{\circ}$ & $111.06^{\circ}$ & 756 & 53 \\
\hline 52 & 护国寺 & 贵州省铜仁市印江土家族苗族自治县梵净山 & $27.91^{\circ}$ & $108.64^{\circ}$ & 1129 & 50,51 \\
\hline 53 & 澄迈金山寺 & 海南省澄迈县金江镇公园路 & $19.74^{\circ}$ & $110.01^{\circ}$ & 1383 & 52 \\
\hline 54 & 永庆寺 & 海南省澄迈县盈滨半岛旅游区 & $19.98^{\circ}$ & $110.10^{\circ}$ & 1029 & 82 \\
\hline 55 & 南山寺 & 海南省三亚市崖州区南山寺文化旅游景区 & $18.29^{\circ}$ & $109.20^{\circ}$ & 1998 & $50,51,72$ \\
\hline 56 & 避暑山庄外八庙 & 河北省承德市避暑山庄 & $40.95^{\circ}$ & $117.96^{\circ}$ & 1713 & 40 \\
\hline 57 & 普陀宗乘之庙 & 河北省承德市狮子沟镇狮子园路 & $41.01^{\circ}$ & $117.93^{\circ}$ & 1771 & 20 \\
\hline 58 & 阳原云盖寺 & 河北省张家口市阳原县东城镇鳌鱼口村 & $40.19^{\circ}$ & $114.41^{\circ}$ & 483 & 50 \\
\hline 59 & 武平寺 & 河南省安阳市林州市河顺镇马家山村 & $36.19^{\circ}$ & $113.88^{\circ}$ & 805 & 23 \\
\hline 60 & 觉仁寺 & 河南省安阳市林州市黄华山景区 & $36.09^{\circ}$ & $113.73^{\circ}$ & 564 & 23 \\
\hline 61 & 石门寺 & 河南省安阳市林州市临淇镇石门寺村 & $35.86^{\circ}$ & $113.91^{\circ}$ & 1644 & 23 \\
\hline 62 & 太平寺 & 河南省安阳市林州市龙山街道西街村 & $36.05^{\circ}$ & $113.85^{\circ}$ & 1356 & 23 \\
\hline 63 & 天平寺 & 河南省安阳市林州市天平山风景区 & $36.06^{\circ}$ & $113.71^{\circ}$ & 542 & 23 \\
\hline 64 & 雪光寺 & 河南省安阳市林州市雪光村 & $36.05^{\circ}$ & $113.85^{\circ}$ & 1498 & 23 \\
\hline 65 & 云峰寺 & 河南省安阳市林州市姚村镇寨底村 & $36.16^{\circ}$ & $113.76^{\circ}$ & 1596 & 23 \\
\hline 66 & 灵泉寺 & 河南省安阳市龙安区 & $36.04^{\circ}$ & $114.08^{\circ}$ & 546 & 23 \\
\hline 67 & 修定寺 & 河南省安阳市清凉山 & $36.20^{\circ}$ & $114.00^{\circ}$ & 494 & 23 \\
\hline 68 & 巡返圆通寺 & 河南省焦作市山阳区 & $35.31^{\circ}$ & $113.31^{\circ}$ & 2010 & 50 \\
\hline 69 & 圆融寺 & 河南省焦作市修武县 & $35.27^{\circ}$ & $113.24^{\circ}$ & 351 & 50 \\
\hline 70 & 大相国寺 & 河南省开封市鼓楼区自由路西段 36 号 & $34.79^{\circ}$ & $114.35^{\circ}$ & 555 & 50 \\
\hline 71 & 白马寺 & 河南省洛阳市洛龙区白马寺镇洛白路 6 号 & $34.72^{\circ}$ & $112.61^{\circ}$ & 68 & 51,83 \\
\hline 72 & 少林寺 & 河南省郑州市登封市嵩山少林风景区 & $34.51^{\circ}$ & $112.94^{\circ}$ & 495 & 50 \\
\hline 73 & 四祖寺 & 湖北省黄冈市黄梅县大河镇四祖村 & $30.12^{\circ}$ & $115.80^{\circ}$ & 624 & 77 \\
\hline 74 & 五祖寺 & 湖北省黄冈市黄梅县五祖镇 & $30.18^{\circ}$ & $115.94^{\circ}$ & 672 & 80 \\
\hline 75 & 大贵寺 & 湖北省随州市广水市三潭风景区 & $30.45^{\circ}$ & $114.87^{\circ}$ & 1614 & 50,51 \\
\hline 76 & 宝通禅寺 & 湖北省武昌区武珞路 549 号 & $30.53^{\circ}$ & $114.34^{\circ}$ & 450 & 30 \\
\hline 77 & 归元寺 & 湖北省武汉市汉阳区翠微路 20 号 & $30.54^{\circ}$ & $114.27^{\circ}$ & 1658 & 31 \\
\hline 78 & 承恩寺 & 湖北省襄阳市谷城县 & $31.99^{\circ}$ & $111.80^{\circ}$ & 612 & 59 \\
\hline 79 & 玉泉寺 & 湖北省宜昌市当阳市 & $30.79^{\circ}$ & $111.69^{\circ}$ & 218 & 81 \\
\hline 80 & 南岳大庙 & 湖南省衡阳市南岳区北支街 2 号 & $27.25^{\circ}$ & $112.73^{\circ}$ & 725 & 48 \\
\hline 81 & 祝圣寺 & 湖南省衡阳市南岳区东街 67 号 & $27.24^{\circ}$ & $112.74^{\circ}$ & 757 & 48 \\
\hline 82 & 藏经殿 & 湖南省衡阳市南岳区南岳衡山风景名胜区 & $27.27^{\circ}$ & $112.68^{\circ}$ & 568 & 48 \\
\hline 83 & 方广寺 & 湖南省衡阳市南岳区南岳衡山风景名胜区 & $27.23^{\circ}$ & $112.64^{\circ}$ & 503 & 48 \\
\hline 84 & 福严寺 & 湖南省衡阳市南岳区南岳衡山风景名胜区 & $27.26^{\circ}$ & $112.70^{\circ}$ & 567 & 48 \\
\hline 85 & 衡山广济寺 & 湖南省衡阳市南岳区南岳衡山风景名胜区 & $27.30^{\circ}$ & $112.71^{\circ}$ & 1597 & 48 \\
\hline 86 & 衡山铁佛寺 & 湖南省衡阳市南岳区南岳衡山风景名胜区 & $27.28^{\circ}$ & $112.70^{\circ}$ & 900 & 51 \\
\hline 87 & 上封寺 & 湖南省衡阳市南岳区南岳衡山风景名胜区 & $27.29^{\circ}$ & $112.70^{\circ}$ & 605 & 48 \\
\hline
\end{tabular}


王新阳, 靳程, 黄力, 周礼华, 郑明铭, 钱深华, 杨永川. 中国佛教寺庙植物多样性和佛教树种替代. 生物多 样性, 2020, 28 (6):668-677. http://www.biodiversity-science.net/CN/10.17520/biods.2019392

\begin{tabular}{|c|c|c|c|c|c|c|}
\hline $\begin{array}{l}\text { 序号 } \\
\text { No. }\end{array}$ & $\begin{array}{l}\text { 寺庙 } \\
\text { Temple }\end{array}$ & $\begin{array}{l}\text { 地址 } \\
\text { Address }\end{array}$ & $\begin{array}{l}\text { 经度 } \\
\text { Longitude (E) }\end{array}$ & $\begin{array}{l}\text { 纬度 } \\
\text { Latitude (N) }\end{array}$ & $\begin{array}{l}\text { 寺庙建成年份 } \\
\text { Year of temple } \\
\text { construction }\end{array}$ & $\begin{array}{l}\text { 附录 } 1 \text { 中参考文献序 } \\
\text { 号 No. of references } \\
\text { in Appendix } 1\end{array}$ \\
\hline 88 & 开福寺 & 湖南省长沙市开福区新河开福寺路 136 号 & $28.22^{\circ}$ & $112.98^{\circ}$ & 927 & 22 \\
\hline 89 & 麓山寺 & $\begin{array}{l}\text { 湖南省长沙市岳麓区登高路 } 58 \text { 号岳麓山风景 } \\
\text { 名胜区 }\end{array}$ & $28.18^{\circ}$ & $112.93^{\circ}$ & 268 & 19, 43 \\
\hline 90 & 地藏寺 & 江苏省南京市鼓楼区阅江楼街道建宁路 202 号 & $32.09^{\circ}$ & $118.75^{\circ}$ & 757 & 2 \\
\hline 91 & 七佛寺 & 江苏省南京市浦口区老山林场红星分场 & $32.10^{\circ}$ & $118.61^{\circ}$ & 1444 & 2 \\
\hline 92 & 㝸率寺 & 江苏省南京市浦口区老山森林汽车公园狮子岭 & $32.06^{\circ}$ & $118.55^{\circ}$ & 1644 & 2 \\
\hline 93 & 惠济寺 & 江苏省南京市浦口区汤泉街道惠济路 & $32.10^{\circ}$ & $118.51^{\circ}$ & 420 & 2 \\
\hline 94 & 栖霞寺 & 江苏省南京市栖霞区栖霞街 84 号 & $32.15^{\circ}$ & $118.96^{\circ}$ & 489 & 2 \\
\hline 95 & 玄焋寺 & 江苏省南京市玄武区北京东路九华山公园 & $32.06^{\circ}$ & $118.81^{\circ}$ & 439 & 2 \\
\hline 96 & 毗卢寺 & 江苏省南京市玄武区汉府街 4 号 & $32.04^{\circ}$ & $118.80^{\circ}$ & 1544 & 2 \\
\hline 97 & 鸡鸣寺 & 江苏省南京市玄武区鸡鸣寺路 1 号 & $32.06^{\circ}$ & $118.80^{\circ}$ & 167 & 2 \\
\hline 98 & 灵谷寺 & 江苏省南京市玄武区灵谷寺路 2 号 & $32.05^{\circ}$ & $118.87^{\circ}$ & 514 & 2 \\
\hline 99 & 喇嘛庙 & 江苏省南京市玄武区玄武湖公园 & $32.07^{\circ}$ & $118.80^{\circ}$ & 1934 & 2 \\
\hline 100 & 寒山寺 & 江苏省苏州市姑苏区枫桥路 & $31.31^{\circ}$ & $120.57^{\circ}$ & 511 & 50,56 \\
\hline 101 & 西园寺 & 江苏省苏州市姑苏区留园路西园弄 18 号 & $31.31^{\circ}$ & $120.59^{\circ}$ & 1279 & 56 \\
\hline 102 & 惠山寺 & 江苏省无锡市梁溪区惠山直街 1 号 & $31.58^{\circ}$ & $120.27^{\circ}$ & 423 & 61 \\
\hline 103 & 宜兴大觉寺 & 江苏省无锡市宜兴市西渚镇香林路 66 号 & $31.24^{\circ}$ & $119.58^{\circ}$ & 1270 & 69 \\
\hline 104 & 大明寺 & 江苏省扬州市邗江区平山堂东路 1 号 & $32.42^{\circ}$ & $119.41^{\circ}$ & 461 & $47,50,55$ \\
\hline 105 & 镇江甘露寺 & 江苏省镇江市京口区东吴路 3 号北固山公园 & $32.22^{\circ}$ & $119.46^{\circ}$ & 265 & 1 \\
\hline 106 & 隆昌寺 & $\begin{array}{l}\text { 江苏省镇江市句容市宝华镇宝华山国家森林公 } \\
\text { 园 }\end{array}$ & $32.14^{\circ}$ & $119.09^{\circ}$ & 502 & 1 \\
\hline 107 & 招隐寺 & 江苏省镇江市林隐路 86 号南山景区 & $32.17^{\circ}$ & $119.45^{\circ}$ & 423 & 1 \\
\hline 108 & 定慧寺 & 江苏省镇江市润州区 & $32.24^{\circ}$ & $119.48^{\circ}$ & 194 & 1 \\
\hline 109 & 金山寺 & 江苏省镇江市润州区金山路 62 号 & $32.22^{\circ}$ & $119.42^{\circ}$ & 317 & 1,50 \\
\hline 110 & 竹林寺 & 江苏省镇江市润州区林隐路 86 号南山景区 & $32.18^{\circ}$ & $119.45^{\circ}$ & 347 & 1 \\
\hline 111 & 百丈寺 & 江西省奉新县百丈山 & $28.69^{\circ}$ & $114.80^{\circ}$ & 772 & 1,51 \\
\hline 112 & 东华寺 & 江西省赣州市石城县石壁镇(福建三明交界) & $26.33^{\circ}$ & $116.45^{\circ}$ & 1592 & 51 \\
\hline 113 & 佛光寺 & 江西省吉安市遂川县戴家埔乡七岭村 & $27.11^{\circ}$ & $114.99^{\circ}$ & 1992 & 51 \\
\hline 114 & 铁佛寺 & 江西省九江市庐山区莲花镇 & $29.60^{\circ}$ & $115.99^{\circ}$ & 638 & 51 \\
\hline 115 & 东林寺 & 江西省九江市庐山区赛阳镇东林村 & $29.41^{\circ}$ & $115.89^{\circ}$ & 384 & 51 \\
\hline 116 & 报国寺 & 江西省九江市庐山区赛阳镇庐山风景区 & $29.53^{\circ}$ & $115.91^{\circ}$ & 1596 & 51 \\
\hline 117 & 净居寺 & 江西省九江市庐山区十里街道南山公园 & $29.67^{\circ}$ & $116.00^{\circ}$ & 2010 & 51 \\
\hline 118 & 真如寺 & 江西省九江市永修县云居山 & $29.09^{\circ}$ & $115.58^{\circ}$ & 808 & 51 \\
\hline 119 & 佑民寺 & 江西省南昌市东湖区民德路 181 号 & $28.68^{\circ}$ & $115.90^{\circ}$ & 511 & 39 \\
\hline 120 & 三缘寺 & 江西省南昌市新建县望城镇幸福村莲花山 & $28.72^{\circ}$ & $115.85^{\circ}$ & 1999 & 71 \\
\hline 121 & 北普陀寺 & 辽宁省锦州市古塔区北普陀山旅游区 & $41.18^{\circ}$ & $121.04^{\circ}$ & 620 & 75 \\
\hline 122 & 义县奉国寺 & 辽宁省锦州市义县东街 18 号 & $41.54^{\circ}$ & $121.25^{\circ}$ & 1020 & 79 \\
\hline 123 & 猪踪朝阳寺 & 辽宁省沈阳市东陵区祝家镇 & $41.73^{\circ}$ & $123.67^{\circ}$ & 700 & 26 \\
\hline 124 & 沈阳大佛寺 & $\begin{array}{l}\text { 辽宁省沈阳市沈河区大南街三段慈恩寺巷 } 14 \\
\text { 号 }\end{array}$ & $41.78^{\circ}$ & $123.45^{\circ}$ & 763 & 26 \\
\hline 125 & 美岱召 & 内蒙古包头市土右旗美岱召镇美岱召村 & $40.62^{\circ}$ & $110.80^{\circ}$ & 1575 & 16 \\
\hline 126 & 乌素图召 & 内蒙古呼和浩特市回民区敒做板镇西乌素图村 & $40.83^{\circ}$ & $111.57^{\circ}$ & 1570 & 16 \\
\hline 127 & 大召 & 内蒙古呼和浩特市玉泉区大召前街 & $40.80^{\circ}$ & $111.65^{\circ}$ & 1579 & 16 \\
\hline 128 & 五当召 & 内蒙古自治区包头市石拐区 & $40.79^{\circ}$ & $110.31^{\circ}$ & 1662 & 16 \\
\hline 129 & 灵武甘露寺 & 宁夏回族自治区银川市灵武市 & $38.30^{\circ}$ & $106.43^{\circ}$ & 629 & 8 \\
\hline 130 & 承天寺 & 宁夏回族自治区银川市兴庆区进宁南街 76 号 & $38.46^{\circ}$ & $106.27^{\circ}$ & 1055 & 8 \\
\hline
\end{tabular}


王新阳, 靳程, 黄力, 周礼华, 郑明铭, 钱深华, 杨永川. 中国佛教寺庙植物多样性和佛教树种替代. 生物多 样性, 2020, 28 (6):668-677. http://www.biodiversity-science.net/CN/10.17520/biods.2019392

\begin{tabular}{|c|c|c|c|c|c|c|}
\hline $\begin{array}{l}\text { 序号 } \\
\text { No. }\end{array}$ & $\begin{array}{l}\text { 寺庙 } \\
\text { Temple }\end{array}$ & $\begin{array}{l}\text { 地址 } \\
\text { Address }\end{array}$ & $\begin{array}{l}\text { 经度 } \\
\text { Longitude (E) }\end{array}$ & $\begin{array}{l}\text { 纬度 } \\
\text { Latitude (N) }\end{array}$ & $\begin{array}{l}\text { 寺庙建成年份 } \\
\text { Year of temple } \\
\text { construction } \\
\end{array}$ & $\begin{array}{l}\text { 附录 } 1 \text { 中参考文献序 } \\
\text { 号 No. of references } \\
\text { in Appendix } 1\end{array}$ \\
\hline 131 & 塔尔寺 & 青海省西宁市湟中县金塔路 56 号 & $36.50^{\circ}$ & $101.57^{\circ}$ & 1377 & 50,51 \\
\hline 132 & 济南灵岩寺 & 山东省济南市长清区万德镇 & $36.36^{\circ}$ & $116.99^{\circ}$ & 390 & 50 \\
\hline 133 & 朝阳寺 & 山东省济宁市邹城市凤凰山 & $35.40^{\circ}$ & $117.34^{\circ}$ & 713 & 51 \\
\hline 134 & 明光寺 & 山东省临沂市平邑县蒙山旅游区 & $35.58^{\circ}$ & $117.84^{\circ}$ & 1280 & 51 \\
\hline 135 & 华严寺 & 山东省青岛市崂山区崂山风景区 & $36.21^{\circ}$ & $120.68^{\circ}$ & 1650 & 9,50 \\
\hline 136 & 甘泉寺 & 山东省求庄市市中区 & $34.93^{\circ}$ & $117.57^{\circ}$ & 1120 & 50 \\
\hline 137 & 青檀寺 & 山东省杰庄市峄城区榴园镇冠世榴园风景区 & $34.78^{\circ}$ & $117.55^{\circ}$ & 727 & 27 \\
\hline 138 & 介休回金寺 & 山西省晋中市介休市绵山镇兴地村 & $36.89^{\circ}$ & $111.93^{\circ}$ & 877 & 76 \\
\hline 139 & 龙泉寺 & 山西省太原市万柏林区 & $37.81^{\circ}$ & $112.47^{\circ}$ & 951 & 68 \\
\hline 140 & 兰若寺 & 山西省忻州市繁峙县东山乡 & $39.17^{\circ}$ & $113.50^{\circ}$ & 763 & 50,51 \\
\hline 141 & 三圣寺 & 山西省忻州市繁峙县砂河镇西沿口龙砂线 & $39.31^{\circ}$ & $113.59^{\circ}$ & 403 & 50 \\
\hline 142 & 普救寺 & 山西省运城市永济市蒲州镇西厢村 & $34.84^{\circ}$ & $110.33^{\circ}$ & 698 & 50 \\
\hline 143 & 法门寺 & 陕西省宝鸡市扶风县法门镇 & $34.44^{\circ}$ & $107.90^{\circ}$ & 68 & 46 \\
\hline 144 & 草堂寺 & 陕西省西安市郬邑区 & $34.01^{\circ}$ & $108.74^{\circ}$ & 401 & 24,50 \\
\hline 145 & 慈恩寺 & 陕西省西安市雁塔区慈恩路 1 号 & $34.22^{\circ}$ & $108.96^{\circ}$ & 648 & 32,50 \\
\hline 146 & 丰德寺 & 陕西省西安市长安区㴒镇街道泮峪口村 & $34.03^{\circ}$ & $108.81^{\circ}$ & 630 & 62 \\
\hline 147 & 净业寺 & 陕西省西安市长安区㴒镇街道后岸山 & $34.02^{\circ}$ & $108.82^{\circ}$ & 581 & 62 \\
\hline 148 & 青云寺 & 陕西省榆林市榆阳区青云乡青云山 & $38.29^{\circ}$ & $109.73^{\circ}$ & 1514 & 36,37 \\
\hline 149 & 东海观音寺 & 上海市奉贤区金汇塘路 999 号 & $30.81^{\circ}$ & $121.51^{\circ}$ & 1368 & 42 \\
\hline 150 & 龙华寺 & 上海市徐汇区龙华镇龙华路 2853 号 & $31.18^{\circ}$ & $121.45^{\circ}$ & 248 & 12 \\
\hline 151 & 川主寺 & 四川省阿坝藏族羌族自治州松潘县 & $32.78^{\circ}$ & $103.62^{\circ}$ & 1270 & 51 \\
\hline 152 & 昭觉寺 & 四川省成都市成华区昭青路 333 号 & $30.71^{\circ}$ & $104.11^{\circ}$ & 638 & $6,34,50$ \\
\hline 153 & 般若寺 & 四川省成都市都江堰市蒲阳镇花溪村一组 & $31.06^{\circ}$ & $103.72^{\circ}$ & 1429 & 50,51 \\
\hline 154 & 灵岩寺 & 四川省成都市都江堰市紫坪铺镇灵岩古街 & $31.02^{\circ}$ & $103.60^{\circ}$ & 479 & 50,51 \\
\hline 155 & 大慈寺 & 四川省成都市锦江区大慈寺路 23 号 & $30.66^{\circ}$ & $104.08^{\circ}$ & 265 & 6,34 \\
\hline 156 & 石经寺 & 四川省成都市龙泉驿区茶店镇石经村 & $30.50^{\circ}$ & $104.35^{\circ}$ & 220 & 34 \\
\hline 157 & 龙兴寺 & 四川省成都市彭州市龙兴北路 1 号 & $30.99^{\circ}$ & $103.94^{\circ}$ & 337 & 51 \\
\hline 158 & 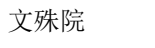 & 四川省成都市青羊区文殊院街 66 号 & $30.68^{\circ}$ & $104.07^{\circ}$ & 611 & 6,34 \\
\hline 159 & 宝光寺 & 四川省成都市新都区宝光街 81 号 & $30.83^{\circ}$ & $104.16^{\circ}$ & 310 & 7 \\
\hline 160 & 大坪寺 & 四川省乐山市峨眉山市峨眉山景区 & $29.57^{\circ}$ & $103.34^{\circ}$ & 1652 & 51 \\
\hline 161 & 大佛禅院 & 四川省乐山市峨眉山市佛光南路 274 号 & $29.59^{\circ}$ & $103.49^{\circ}$ & 1605 & 18 \\
\hline 162 & 万年寺 & 四川省乐山市峨眉山市黄湾乡峨眉山景区 & $29.58^{\circ}$ & $103.39^{\circ}$ & 401 & 50,51 \\
\hline 163 & 慈云寺 & 四川省眉山市洪雅县九莲山 & $29.92^{\circ}$ & $103.38^{\circ}$ & 1030 & 50,73 \\
\hline 164 & 白山寺 & $\begin{array}{l}\text { 四川省南充市高坪区和平东路 } 103 \text { 号凌云山景 } \\
\text { 区 }\end{array}$ & $30.75^{\circ}$ & $106.20^{\circ}$ & 465 & 44,50 \\
\hline 165 & 清泉寺 & 四川省南充市顺庆区舞凤镇清泉寺路 & $30.84^{\circ}$ & $106.12^{\circ}$ & 958 & 41 \\
\hline 166 & 天池寺 & 四川省自贡市贡井区天池路 188 号 & $29.35^{\circ}$ & $104.71^{\circ}$ & 1383 & 67 \\
\hline 167 & 中台禅寺 & 台湾省南投县埔里镇一新里中台路 1 号 & $23.97^{\circ}$ & $120.96^{\circ}$ & 1994 & 50 \\
\hline 168 & 罗布林卡 & 西藏自治区拉萨市城关区罗布林卡路 21 号 & $29.65^{\circ}$ & $91.09^{\circ}$ & 1740 & $29,50,51$ \\
\hline 169 & 宝莲寺 & 香港离岛区昂坪 & $22.26^{\circ}$ & $113.91^{\circ}$ & 1924 & 50 \\
\hline 170 & 曹溪寺 & 云南省昆明市安宁市镇龙溪路 & $24.95^{\circ}$ & $102.45^{\circ}$ & 1107 & 60 \\
\hline 171 & 县华寺 & 云南省昆明市盘龙区县华路 & $25.05^{\circ}$ & $102.75^{\circ}$ & 1636 & 51,66 \\
\hline 172 & 妙高寺 & $\begin{array}{l}\text { 云南省昆明市五华区黑林铺街道办事处海源社 } \\
\text { 区龙院村三华山 }\end{array}$ & $25.10^{\circ}$ & $102.63^{\circ}$ & 1235 & 60 \\
\hline 173 & 族竹寺 & 云南省昆明市五华区玉案山 & $25.07^{\circ}$ & $102.63^{\circ}$ & 1280 & 50,60 \\
\hline 174 & 普济寺 & 云南省丽江市古城区束河街道中济社区普济村 & $26.85^{\circ}$ & $100.23^{\circ}$ & 1771 & 5,50 \\
\hline
\end{tabular}


王新阳, 靳程, 黄力, 周礼华, 郑明铭, 钱深华, 杨永川. 中国佛教寺庙植物多样性和佛教树种替代. 生物多 样性, 2020, 28 (6):668-677. http://www.biodiversity-science.net/CN/10.17520/biods.2019392

\begin{tabular}{|c|c|c|c|c|c|c|}
\hline $\begin{array}{l}\text { 序号 } \\
\text { No. }\end{array}$ & $\begin{array}{l}\text { 寺庙 } \\
\text { Temple }\end{array}$ & $\begin{array}{l}\text { 地址 } \\
\text { Address }\end{array}$ & $\begin{array}{l}\text { 经度 } \\
\text { Longitude (E) }\end{array}$ & $\begin{array}{l}\text { 纬度 } \\
\text { Latitude (N) }\end{array}$ & $\begin{array}{l}\text { 寺庙建成年份 } \\
\text { Year of temple } \\
\text { construction }\end{array}$ & $\begin{array}{l}\text { 附录 } 1 \text { 中参考文献序 } \\
\text { 号 No. of references } \\
\text { in Appendix } 1\end{array}$ \\
\hline 175 & 玉峰寺 & 云南省丽江市玉龙县白沙镇白沙村 & $26.99^{\circ}$ & $100.20^{\circ}$ & 1700 & 5,50 \\
\hline 176 & 文峰寺 & 云南省丽江市玉龙县黄山镇文华村 & $26.81^{\circ}$ & $100.18^{\circ}$ & 1733 & 5,50 \\
\hline 177 & 指云寺 & 云南省丽江市玉龙县拉市乡海南村 & $26.86^{\circ}$ & $100.10^{\circ}$ & 1727 & 5 \\
\hline 178 & 圣山寺庙群 & 云南省西双版纳傣族自治州 & $22.01^{\circ}$ & $100.80^{\circ}$ & 615 & 28 \\
\hline 179 & 石室寺 & 浙江省杭州市临安区和尚坪 & $30.07^{\circ}$ & $119.23^{\circ}$ & 969 & 54 \\
\hline 180 & 禅源寺 & 浙江省杭州市临安市西天目山 & $30.32^{\circ}$ & $119.45^{\circ}$ & 1425 & 51,54 \\
\hline 181 & 净慈寺 & 浙江省杭州市南山路 56 号 & $30.23^{\circ}$ & $120.15^{\circ}$ & 954 & 13 \\
\hline 182 & 灵隐寺 & 浙江省杭州市西湖区法云弄 1 号 & $30.24^{\circ}$ & $120.10^{\circ}$ & 326 & $13,14,50$ \\
\hline 183 & 虎跑 & 浙江省杭州市西湖区虎跑路 39 号 & $30.21^{\circ}$ & $120.13^{\circ}$ & 819 & 14,51 \\
\hline 184 & 法净禅寺 & 浙江省杭州市西湖区天竺路 112 号 & $30.23^{\circ}$ & $120.10^{\circ}$ & 597 & 13 \\
\hline 185 & 法喜寺 & 浙江省杭州市西湖区天竺路 338 号 & $30.23^{\circ}$ & $120.10^{\circ}$ & 934 & 13,14 \\
\hline 186 & 天童寺 & $\begin{array}{l}\text { 浙江省宁波市鄞州区东吴镇太白山天童森林公 } \\
\text { 园 }\end{array}$ & $29.81^{\circ}$ & $121.80^{\circ}$ & 300 & 50 \\
\hline 187 & 大佛寺 & 浙江省绍兴市新昌县关城镇人民西路 117 号 & $29.50^{\circ}$ & $120.89^{\circ}$ & 516 & 50 \\
\hline 188 & 国清寺 & 浙江省台州市天台县赤城街道国清景区 & $29.17^{\circ}$ & $121.05^{\circ}$ & 598 & $17,50,51$ \\
\hline 189 & 舟山金山寺 & 浙江省舟山市普陀区六横镇荷花村 & $29.75^{\circ}$ & $122.11^{\circ}$ & 1688 & 51 \\
\hline 190 & 舟山普济寺 & 浙江省舟山市普陀山香华街 15 号 & $29.99^{\circ}$ & $122.21^{\circ}$ & 916 & 35,51 \\
\hline 191 & 慧济寺 & 浙江省舟山市普陀山香云路 208 号 & $30.01^{\circ}$ & $122.39^{\circ}$ & 1471 & 10 \\
\hline
\end{tabular}


王新阳, 靳程, 黄力, 周礼华, 郑明铭, 钱深华, 杨永川. 中国佛教寺庙植物多样性和佛教树种替代. 生物多

样性, 2020, 28 (6):668-677. http://www.biodiversity-science.net/CN/10.17520/biods.2019392

\section{附录3 佛教树种鉴定参考文献}

Appendix 3 References for identifying Buddhist tree species

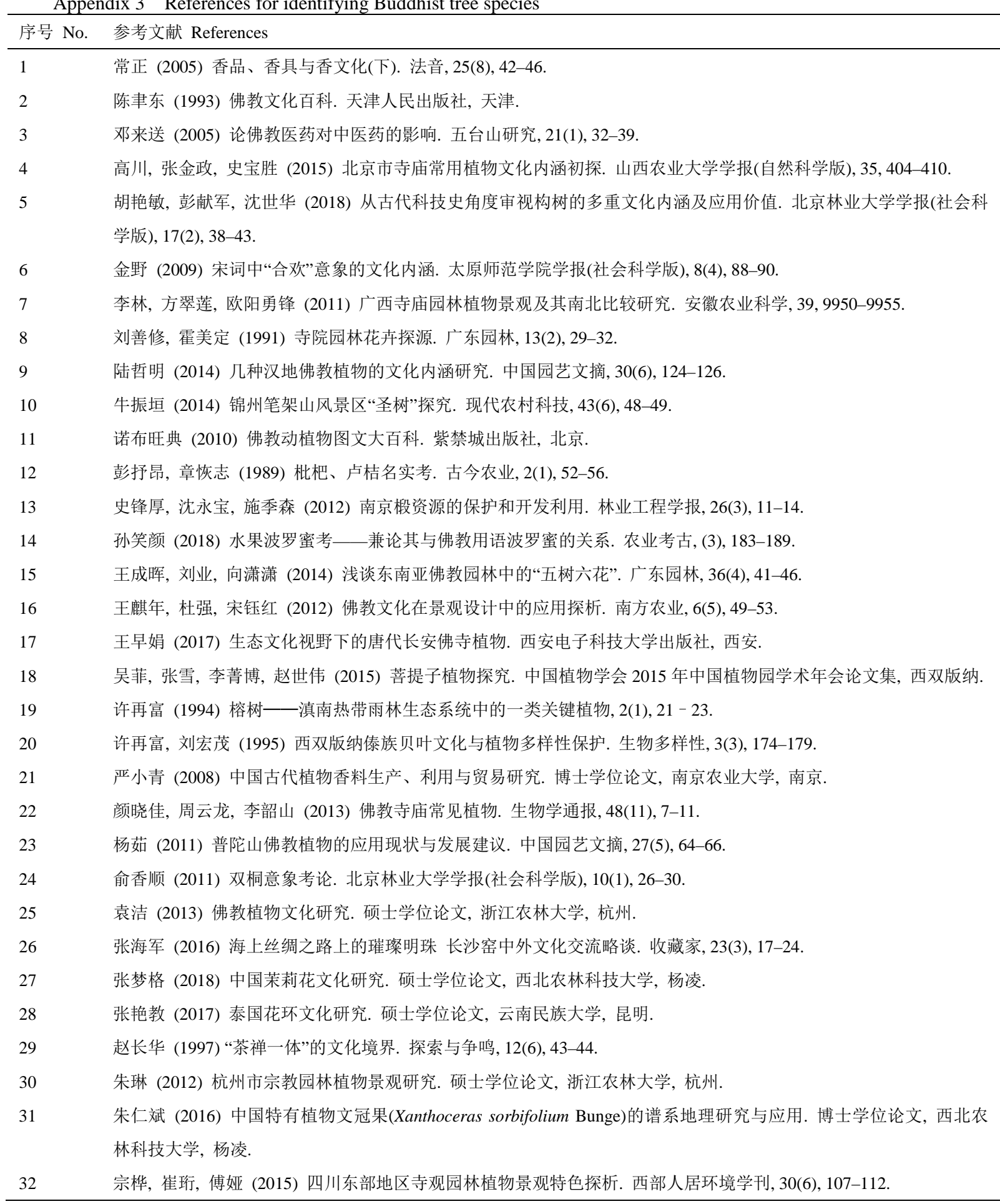


王新阳, 靳程, 黄力, 周礼华, 郑明铭, 钱深华, 杨永川. 中国佛教寺庙植物多样性和佛教树种替代. 生物多 样性, 2020, 28 (6):668-677. http://www.biodiversity-science.net/CN/10.17520/biods.2019392

附录4 中国寺庙中常见的原始佛教树种及其在中国的替代佛教树种

Appendix 4 Original Buddhist tree species and their alternative Buddhist tree species in China

\begin{tabular}{|c|c|c|c|}
\hline $\begin{array}{l}\text { 佛教文化含义 } \\
\text { Buddhist cultural } \\
\text { values }\end{array}$ & $\begin{array}{l}\text { 原始佛教树种 } \\
\text { Original Buddhist tree species }\end{array}$ & $\begin{array}{l}\text { 替代佛教树种 } \\
\text { Alternative Buddhist tree species }\end{array}$ & $\begin{array}{l}\text { 附录 } 3 \text { 中参考文献序号 } \\
\text { No. of references in } \\
\text { Appendix } 3\end{array}$ \\
\hline 觉悟 & 菩提树 Ficus religiosa & $\begin{array}{l}\text { 银杏 Ginkgo biloba, 椴树属树种 Tilia spp., 暴马丁香 } \\
\text { Syringa reticulata subsp. amurensis, 黑弹树 Celtis } \\
\text { bungeana, 黄葛树 Ficus virens var. sublanceolata, 楸 } \\
\text { Catalpa bungei }\end{array}$ & $4,10,13,22,32$ \\
\hline 无忧 & 无忧树 Saraca asoca* & $\begin{array}{l}\text { 中国无忧花 Saraca dives, 垂柳 Salix babylonica, 旱柳 } \\
\text { Salix matsudana, 枇杷 Eriobotrya japonica, 合欢 } \\
\text { Albizia julibrissin, 刺桐 Erythrina variegate }\end{array}$ & $6,11,12,22$ \\
\hline 涅槃 & 娑罗双 Shorea robusta* & $\begin{array}{l}\text { 云南娑罗双 Shorea assamica, 七叶树 Aesculus } \\
\text { chinensis, 梭罗树属树种 Reevesia spp., 梧桐属树种 } \\
\text { Firmiana spp., 杪椤属树种 Alsophila spp. }\end{array}$ & $4,24,26$ \\
\hline 比相 & 苹婆 Sterculia nobilis & $\begin{array}{l}\text { 苹果 Malus pumila, 罗汉松属树种 Podocarpus spp., 假 } \\
\text { 苹婆 Sterculia lanceolata }\end{array}$ & 11,30 \\
\hline 小因大果 & $\begin{array}{l}\text { 印度榕 Ficus elastic, } \\
\text { 石榴 Punica granatum }\end{array}$ & - & 11 \\
\hline 无常 & 乌墨 Syzygium cumini* & 蒲桃属树种 Syzygium spp. & 2 \\
\hline 空无 & - & 苏铁属树种 Cycas spp. & 23 \\
\hline 清心寡欲 & - & 山茶属树种 Camellia spp. & 29 \\
\hline 消灾 & 高山榕 Ficus altissima & 南天竹 Nandina domestica & 16,19 \\
\hline 刻经 & $\begin{array}{l}\text { 贝叶棕 Corypha } \\
\text { umbraculifera }\end{array}$ & $\begin{array}{l}\text { 棕㭣 Trachycarpus fortune, 蒲葵 Livistona chinensis, 棕 } \\
\text { 竹 Rhapis excels, 构属树种 Broussonetia spp., 青檀 } \\
\text { Pteroceltis tatarinowii }\end{array}$ & $5,7,20$ \\
\hline 佛珠 & $\begin{array}{l}\text { 无患子 Sapindus } \\
\text { saponaria }\end{array}$ & $\begin{array}{l}\text { 奕树属树种 Koelreuteria spp., 楝 Melia azedarach, 山 } \\
\text { 桃 Amygdalus davidiana, 杜英 Elaeocarpus decipiens, } \\
\text { 梆子 Cocos nucifera, 南酸杳 Choerospondias axillaris, } \\
\text { 酒瓶椰子 Hyophorbe lagenicaulis, 酸梞 Ziziphus jujuba } \\
\text { var. spinosa, 鱼尾葵 Caryota maxima, 六道木 Zabelia } \\
\text { biflora }\end{array}$ & 9,18 \\
\hline 医药 & $\begin{array}{l}\text { 诃子属树种 Terminalia } \\
\text { spp. }\end{array}$ & 枇杷 Eriobotrya japonica & 3,17 \\
\hline 花供 & $\begin{array}{l}\text { 黄兰 Michelia champaca, } \\
\text { 白兰 Michelia × alba, } \\
\text { 鸡蛋花 Plumeria rubra } \\
\text { cv. 'Acutifolia' } \\
\text { 茉莉花 Jasminum sambac }\end{array}$ & $\begin{array}{l}\text { 橾子 Gardenia jasminoides, 含笑属树种 Michelia spp., } \\
\text { 牡丹 Paeonia suffruticosa, 山玉玉兰 Lirianthe delavayi, } \\
\text { 玉兰 Yulania denudate, 瑞香属树种 Daphne spp., 木本 } \\
\text { 曼陀罗 Datura arborea }\end{array}$ & $8,17,22,27,28$ \\
\hline 果供 & $\begin{array}{l}\text { 槟榔 Areca catechu, } \\
\text { 糖棕 Borassus flabellifer }\end{array}$ & 波罗蜜 Artocarpus heterophyllus & 14,15 \\
\hline 香供 & $\begin{array}{l}\text { 越南安息香 Styrax } \\
\text { tonkinensis* }\end{array}$ & $\begin{array}{l}\text { 安息香属 Styrax spp., 侧柏 Platycladus orientalis, 柏木 } \\
\text { Cupressus funebris, 圆柏 Juniperus chinensis, 乌檀 }\end{array}$ & $1,21,25$ \\
\hline 灯供 & 娑罗双 Shorea robusta* & $\begin{array}{l}\text { 铁力木 Mesua ferrea, 石栗 Aleurites moluccana, 文冠 } \\
\text { 果 Xanthoceras sorbifolium }\end{array}$ & 20,31 \\
\hline
\end{tabular}

“*”表示该树种没有在本研究被记录到。“*” indicates that the species have not been recorded in our study. 